Jurnal Akuntansi dan Investasi, Vol. 18 No. 1, Hlm: 80-101, Januari 2017

Artikel ini tersedia di website: http://journal.umy.ac.id/index.php/ai

DOI: $10.18196 /$ jai.18162

\title{
Hubungan Faktor Internal dan Eksternal terhadap Proses Pengambilan Keputusan Etis
}

\author{
Niluh Putu Dian Rosalina Handayani Narsa * Kadek Pranetha Prananjaya \\ Program Studi Akuntansi, Universitas Airlangga, Kampus B Jl. Airlangga No. 4 Surabaya, Indonesia
}

\begin{tabular}{l}
\hline A R T I C L E I N F O \\
\hline Article history: \\
received 28 Sep 2016 \\
revised 2 Okt 2016 \\
accepted 24 Nov 2016
\end{tabular}

Keywords:

Educational Level;

Ethical Decision

Making; Moral Intensity;

Personal Moral

Philosophy

\begin{abstract}
A B S TRACT
This study aims to examine the relationship of two factors, namely internal factors (based on the individual characteristics: personal moral philosophy which is consisting of idealism and relativism, education level, gender and age) as well as external factors (moral intensity which has six variables, namely the magnitude of the consequences, social consensus, probability of effect, temporal immediacy, concentration of effect, and proximity) to the three-stage of ethical decision-making processes (ethical recognition, judgment and intention). A significant body of work within the business ethics literature has been focused on the internal and external factors which mainly have significant impact on the way individual respond to ethical issues. Data collected used survey method. Respondents are undergraduate and graduate students of accounting. A total of 173 respondents had fill out questionnaires completely. Analyis data used hierarchical linear regression, independent t-test and one-way anova. The findings show that some of the variables tested had a significant relationship as predicted in all of the three stage of ethical decision-making processes with a difference in level of significance. However, no significant relationship was found regarding the relationship of age in all of the three stages, as well as the the evidence of a significant relationship that is inconsistent with the predictions regarding the relationship of gender in the stages of ethical intention and the relationship of probability of effect and proximity in the stages of ethical recognition. The implications of this study are there is a need to give more attention to ethics in accounting education and also the need to encourage the idealistic philosophy.
\end{abstract}

(C) 2017 JAI. All rights reserved

\section{PENDAHULUAN}

Terjadinya kasus-kasus permasalahan etika pada dunia bisnis dan profesi terutama di bidang akuntansi -seperti kasus Enron dan WorldComyang mana pada dasarnya berakar dari pelanggaran prinsip-prinsip etis, memicu timbulnya pertanyaan mengenai kredibilitas seorang akuntan profesional terutama terkait dengan pengambilan keputusan etis (Haron et al., 2015). Pengambilan keputusan etis sebagai variabel dependen dilatarbelakangi dilema atau isu dihadapi oleh akuntan. Luasnya manfaat dan dampak keputusan akuntan, membuat pertimbangan akuntan atas keputusannya menjadi sangat penting (Pangesti, 2014).

Sesuai dengan rerangka teoretis dari Rest (1979), terdapat empat tahapan berurutan dalam proses pengambilan keputusan etis, yakni ethical recognition, ethical judgment, ethical intention, dan ethical behavior. Hasil penelitian telah menunjuk- kan bahwa keempat tahapan pengambilan keputusan etis tersebut saling berasosiasi satu sama lain dan dapat dipengaruhi oleh beberapa faktor eksternal dan internal (Chan dan Leung, 2006; Arestanti et al., 2016). Variabel internal berkaitan dengan faktor individual, seperti tingkat pendidikan, gender, usia, dan filosofi moral personal. Penelitian mengenai penginvestigasian variabelvariabel tersebut telah banyak dilakukan, namun masih terdapat temuan yang belum konklusif.

Menurut Rest (1986), tingkat pendidikan dan usia dapat memengaruhi peningkatan Cognitive Moral Development (CMD) individu. Peningkatan CMD menunjukkan bahwa tingkat landasan moral mengalami peningkatan dimana kemampuan untuk mempertimbangkan terkait dengan isu moral menjadi lebih baik (Kohlberg, 1976). Penelitian yang dilakukan oleh Browning dan Zabriskie (1983), Cohen et al. (2001) dan O'Fallon dan Butterfield (2005) menyatakan bahwa tingkat pen- 
didikan memiliki pengaruh yang signifikan terhadap pengambilan keputusan etis. Hasil yang berbeda ditemukan Shafer (2001), Cagle dan Baucus (2006) dan Benarnd dan Sweeney (2010) yang menyatakan bahwa tingkat pendidikan tidak memiliki pengaruh terhadap pengambilan keputusan etis. Dapat disimpulkan, temuan dari penelitianpenelitian tersebut memperlihatkan ketidakkonsistenan hasil terhadap teori yang dikemukan oleh Rest, sehingga pengaruh level pendidikan dan usia terhadap pengambilan keputusan etis masih menarik untuk dilakukan.

Terkait perbedaan gender, telah banyak penelitian yang mendiskusikan hal tersebut secara teoretis dan penjelasan telah banyak pula dieksplorasi untuk menemukan penjelasan rasional atas perbedaan tersebut, salah satunya adalah teori sosialisasi gender (Betz et al., 1989; Nguyen et al., 2008). Perspektif pria dan wanita terkait isu etika adalah berbeda. Pria lebih fokus pada pencapaian kesuksesan sehingga cenderung untuk mengabaikan aturan, berbeda dengan wanita. Analisis meta pun telah dilakukan untuk merekonsiliasi temuan terkait pengaruh dari jenis kelamin tersebut, yakni Jaffee dan Hyde (2000), dan temuan mereka mendukung teori tersebut. Namun, hasil penelitian tersebut umumnya berasal dari negara bagian barat, dan terdapat kemungkinan hasil tersebut kemungkinan akan berbeda mengingat Indonesia, negara bagian timur, memiliki budaya yang berbeda. Terlebih juga masih terdapat temuan yang belum konsisten terkait gender. Selain itu terdapat fenomena pula bahwa saat ini di lingkungan bisnis telah banyak wanita yang mencapai level tinggi di posisi manajerial (Nguyen et al., 2008). Sehingga masih penting untuk menginvestigasi pengaruh dari gender terhadap proses pengambilan keputusan etis.

Selanjutnya, Gowing et al. (2005), Abdolmohammadi dan Baker (2006), Fritzsche dan $\mathrm{Oz}$ (2007) menyatakan bahwa filosofi moral personal memiliki pengaruh terhadap pengambilan keputusan etis. Filosofi moral personal berkaitan dengan aturan dan prinsip-prinsip yang dipertimbangkan oleh individu saat pembuatan keputusan untuk membedakan antara benar dan salah (Ferrell dan Fraedrich, 1997). Seorang akuntan profesional dalam melaksanakan suatu pekerjaan harus memiliki nilai-nilai individual yang dijadikan pertimbangan dalam pengambilan suatu keputusan (Schlenker dan Forsyth, 1977). Penyimpanganpenyimpangan atas keputusan yang dibuat oleh seorang akuntan seperti kasus di atas menyebabkan penelitian mengenai filosofi moral personal menjadi sangat penting. Hasil penelitian mengenai filosofi moral personal menyimpulkan bahwa moral filosofi yang berbeda antar individu (idealism dan relativism) akan menghasilkan keputusan yang berbeda.

Di sisi lain, contoh dari faktor eksternal yang memengaruhi empat tahapan proses pengambilan keputusan etis adalah variabel organisasional seperti kode etik, ilim etis, ukuran organisasi, tipe industri. Namun demikian, sebelum tahun 1991, penelitian mengenai etika bisnis hampir keseluruhannya memfokuskan pada penginvestigasian variabel individual dan organisasional yang mempengaruhi proses pengambilan keputusan etis. Hingga akhirnya di tahun 1991, Jones pertama kali memberikan gagasan bahwa pengambilan keputusan etis juga dipengaruhi oleh faktor di luar individu yaitu intensitas moral (Leitsch, 2004). Intensitas moral merupakan tingkat isu yang berkaitan dengan imperatif moral atas suatu situasi (Jones, 1991).

Meskipun penelitian mengenai pengaruh dari berbagai variabel individual dan intensitas moral telah banyak dilakukan oleh peneliti, namun masih terdapat gap penelitian bahwa masih sedikit terdapat bukti empiris mengenai penelitian tersebut terutama di negara berkembang seperti di Indonesia. Selain itu dari penjabaran di atas, dapat disimpulkan secara keseluruhan masih terdapat inkonsistensi temuan penelitian-penelitian sebelumnya mengenai pengaruh dari variabel individual seperti tingkat pendidikan, usia, gender, dan filosofi moral personal terhadap tahapan dalam proses pengambilan keputusan etis.

Penelitian ini hanya melihat tiga tahapan dari proses pengambilan keputusan etis, yakni ethical recognition, ethical judgment, dan ethical intention. Alasan tidak digunakannya ethical behavior karena untuk menginvestigasinya, diperlukan waktu dan biaya yang cukup besar. Tujuan yang ingin dicapai oleh penelitian ini adalah menguji secara komprehensif hubungan dari variabel individual (tingkat pendidikan, usia, gender, dan filosofi moral personal) serta variabel eksternal (intensitas moral) terhadap proses pengambilan keputusan etis dari mahasiswa sarjana akuntansi dan mahasiswa pascasarjana akuntansi. Pemilihan mahasiswa akuntansi sebagai responden dalam penelitian ini adalah karena mahasiswa akuntansi nantinya akan memiliki peran sebagai akuntan di berbagai instansi dan perusahaan.

Penelitian ini diharapkan dapat menambah bukti empiris dari literatur mengenai pengambilan keputusan etis di lingkup bisnis terutama dengan 
menggunakan dua jenis kelompok mahasiswa akuntansi yang berbeda jenjang pendidikan serta diharapkan dapat memberikan bahan masukan bagi pihak akademisi dalam menyusun kurikulum pembelajaran untuk mahasiswanya agar kemampuan mahasiswa dalam mengndentifikasi isu-isu etis menjadi meningkat.

Bagian selanjutnya dari artikel ini akan dijabarkan mengenai beberapa literatur dan argumen teoritis, diikuti pembahasan atas metode pengumpulan dan analisis data berikut hasil-hasil yang menjadi temuan. Artikel ini kemudian ditutup dengan penyampaian simpulan, implikasi, saran serta keterbatasan penelitian.

\section{TINJAUAN LITERATUR DAN PERUMUSAN HIPOTESIS}

\section{Pengambilan Keputusan Etis}

Pengambilan keputusan merupakan proses identifikasi dan pemilihan suatu tindakan untuk merespon suatu permasalahan atau kesempatan (Langley et al., 1995). Proses pengambilan keputusan etis, menurut Carlson et al. (2002), adalah "a process by which individuals use their base to determine whether a certain issue is right or wrong".

Rest (1979; 1986) mengajukan empat tahapan sekuensial dari proses pengambilan keputusan etis untuk mendeskripsikan kognitif individual ketika mereka dihadapi oleh dilema etika. Keempat tahapan tersebut yang pertama adalah ethical recognition. Tahapan ini berkaitan dengan kemampuan seseorang untuk menginterpretasikan situasi tertentu adalah etis atau tidak etis. Tahapan kedua adalah ethical judgment, dimana pada tahapan ini individu menentukan tindakan seperti apakah yang secara moral adalah benar. Selanjutnya tahapan ketiga adalah ethical intention. Pada tahapan tersebut individu mulai memprioritaskan suatu alternatif etis tertentu dibandingkan alternatif lainnya. Terakhir adalah ethical behavior, yakni individu benarbenar melakukan tindakan yang etis.

Setiap tahapan adalah berbeda secara konseptual, dan kesuksesan di salah satu tahapan tidak berarti juga akan sukses di tahapan selanjutnya. Para peneliti di bidang bisnis dari berbagai area seperti pemasaran, audit, manajemen telah mengadopsi rerangka milik Rest tersebut dalam penelitian mereka. Ada yang hanya menguji di salah satu tahap dan ada juga yang menginvestigasi di dua atau lebih tahap (Musbah, 2010).
Ethical recognition merupakan tahapan fundamental dan krusial dalam proses pengambilan keputusan etis. Rest (1986) berargumen bahwa kemampuan untuk mengidentifikasi dan secara tepat menilai isu etis dalam suatu situasi tertentu merupakan prasyaarat yang penting dalam mencapai keputusan etis yang tepat. Selanjutnya, ethical judgment memiliki elemen utama kemampuan kognitif seseorang ketika dihadapkan oleh isu etis untuk membedakan antara yang benar dan yang salah, sehingga dengan kata lain tahapan ini utamanya didasarkan pada Cognitive Moral Develop ment (CMD), namun penelitian ini tidak ditujukan untuk mengelaborasi secara ekstensif aspek teoretis dari CMD. Kedua tahapan tersebut dipengaruhi oleh berbagai faktor seperti variabel individual dan karakteristik dari problem etis itu sendiri. Kedua tahapan ini juga masih berkaitan dengan proses kognitif yang menjadi penyebab dari munculya ethical intention dan ethical behavior:

Tahapan ethical intention sendiri salah satunya dipengaruhi oleh intensi yang ada pada diri individu. Ajzen dan Fishbein (1980) menjelaskan tentang theory of reason action (TRA) dan Theory Planned Behaviour (TPB) yang menjelaskan mengenai intensi etis.Teori tersebut menjelaskan bahwa intensi berkaitan dengan hasil pengambilan keputusan untuk melakukan atau tidak melakukan suatu tindakan. Teori ini telah diuji oleh beberapa peneliti, salah satunya Oumlil dan Balloun (2008) yang membuktikan bahwa keputusan dalam bertindak atas suatu masalah dipengaruhi oleh intensi seorang individu tersebut. Hal ini berarti intensi memiliki peran untuk menentukan tindakan atau keputusan yang akan diambil oleh seseorang.

Sesuai dengan model yang dibangun oleh Rest et al. (1986) dan Jones (2001), ethical intention merupakan outcome yang paling penting yang sebelumnya dipengaruhi oleh pertimbangan etis (ethical judgement). Ethical intention merupakan tahap dimana individu akan menitikberatkan nilainilai etika dalam kaitannya terhadap nilai lain. Ajzen (1991) mengatakan bahwa tahap intensi etis merupakan salah satu prediktor yang paling signifikan untuk perilaku yang akan diambil selanjutnya oleh individu, khususnya jika lingkup pengambilan keputusan tersebut bersfiat spesifik. Sehingga sebenarnya dengan mengeksplorasi sampai tahapan ini saja sudah cukup, terlebih lagi untuk menginvestigasi tahapan ethical behavior akan memerlukan waktu dan biaya yang besar karena merupakan hal yang susah untuk mengukur perilaku etis seseorang. 


\section{Filosofi Moral Personal}

Individu dalam proses pembuatan keputusan sering digerakkan oleh munculnya suatu masalah yang membutuhkan solusi ataupun respon, dan seringkali membentuk tindakan (Jones, 1991). Untuk memulai proses pembuatan keputusan moral, seseorang harus mampu mengenali isu moral. Isu moral muncul ketika tindakan seseorang dapat merugikan ataupun menguntungkan orang lain. Kemampuan seseorang dalam mempertimbangkan isu moral terkait dengan masalah yang dimiliki akan bergantung kepada filosofi moral yang dimiliki oleh individu tersebut.

Filosofi moral berkaitan dengan aturan dan prinsip-prinsip yang dipertimbangkan oleh individu saat pembuatan keputusan untuk membedakan antara benar dan salah (Ferrell dan Fraedrich, 1997). Filosofi moral ini dapat berpengaruh dalam proses pengambilan keputusan etis (O'Fallon dan Butterfield, 2005). Schlenker and Forsyth (1977) menyatakan bahwa seorang individu dalam membuat pertimbangan etika (ethical judgement) ditentukan oleh dua faktor yaitu idealisme dan relativisme. Idealisme mengarah pada tingkatan individu yang mempercayai bahwa konsekuensi yang diinginkan akan selalu bisa diperoleh tanpa melakukan pelanggaran aturan moral. Berbeda dengan idealisme, relativisme mengarah pada tingkatan individu yang menolak aturan universal dalam memandu mereka bersikap. Hal ini memperlihatkan bahwa individu relativisme lebih fleksibel dibandingkan dengan individu idealisme sehingga pandangan mereka terhadap isu etis atas suatu permasalahan akan berbeda.

Musbah (2010) menyatakan bahwa individu dengan level idealisme tinggi dan relativisme rendah mempercayai bahwa tindakan mereka harus sesuai dengan aturan moral universal dan menghasilkan konsekuensi yang positif, sedangkan individu dengan level idealime rendah dan relativisme tinggi tidak meyakini bahwa perilaku negatif tidak harus selalu dihindari, karena merugikan sesorang terkadang dibutuhkan untuk memperoleh hasil yang bermanfat bagi banyak orang. Sebagai contoh, individu relativisme akan mendispensasi tindakan pencurian yang dilakukan oleh seseorang untuk kepentingan orang banyak sedangkan untuk individu idealisme menganggap tindakan tersebut bukanlah suatu tindakan yang diperbolehkan. Oleh sebab itu, maka peneliti mengajukan hipotesis:

H1: Idealisme berhubungan positif dengan: (a) ethical recognition, (b) ethical judgment,(c) ethical intention.
H2: Relativisme berhubungan negatif dengan (a) ethical recognition, (b)ethical judgment, (c) ethical intention.

\section{Intensitas Moral}

Intensitas moral (moral intensity) yang digunakan dalam penelitian ini berkaitan dengan tingkat isu yang berkaitan dengan imperatif moral atas suatu situasi (Jones, 1991). Individu yang menganggap bahwa intensitas moral atas suatu situasi rendah, maka ia tidak akan merasa adanya permasalahan etika atas situasi tersebut. Hal yang berbeda terjadi jika individu menganggap bahwa intensitas moral atas suatu situasi tinggi, maka ia akan merasa adanya permasalahan etis atas situasi tersebut. Ajzen (1991) menggarisbawahi bahwa hubungan antara dimensi dari intensitas moral dengan intensi etis adalah sangat penting. Jones (1991) menyatakan bahwa komponen-komponen yang memengaruhi intensitas moral yaitu: magnitude of consequences, probability effect, temporal immediacy, social consencus, , concentration of effect, dan proximity. Penjelasan masing-masing komponen sebagai berikut:

(1) Besaran Konsekuensi (Magnitude of Consequences), didefinisikan sebagai jumlah kerugian (manfaat) yang dihasilkan oleh pengorbanan (kebermanfaatan) dari sebuah tindakan moral.

(2) Konsensus Sosial (Social Consensus) didefinisikan sebagai tingkat kesepakatan sosial bahwa sebuah tindakan dianggap benar atau salah.

(3) Probabilitas Efek (Probability of Effect) merupakan sebuah fungsi bersama dari kemungkinan bahwa tindakan tertentu akan secara aktual mengambil tempat dan tindakan tersebut akan secara aktual menyebabkan kerugian (manfaat) yang terprediksi

(4) Kesegeraan Temporal (Temporal Immediacy) adalah jarak atau waktu antara pada saat terjadi dan awal mula konsekuensi dari sebuah tindakan moral tertentu (waktu yang makin pendek menunjukkan kesiapan yang lebih besar).

(5) Efek Konsentrasi (Concentration of Effect) adalah sebuah fungsi invers dari jumlah orang yang memengaruhi dan dipengaruhi oleh sebuah tindakan yang dilakukan.

(6) Kedekatan (Proximity) adalah perasaan kedekatan (sosial, budaya, psikologi, atau fisik) yang dimiliki oleh pembawa moral untuk si pelaku dari kejahatan (kemanfaatan) dari 
suatu tindakan tertentu. Orang lebih peduli mengenai orang lain yang dekat dengannya (secara sosial, budaya, psikologis, fisik) dibandingkan dengan orang yang jauh.

Penelitian ini akan menggunakan semua komponen dari intensitas moral yang telah dikemukan oleh Jones (1991). Hal ini dilatarbelakangi karena penelitian ini ingin membuktikan bahwa seluruh komponen tersebut akan berkontribusi dalam memprediksi intensitas moral. Jones (1991) menyatakan bahwa masing-masing dari komponen intensitas moral tersebut merupakan variabel independen yang akan memiliki pengaruh secara signifikan di masing-masing tahapan pengambilan keputusan etis. Selain itu terdapat sebuah panggilan untuk melakukan penelitian terkait hal tersebut karena bukti empiris yang ada masih sangat sedikit (O'Fallon dan Butterfield, 2005). Oleh sebab itu, peneliti mengajukan hipotesis sebagai berikut:

H3: Besaran konsekuensi (Magnitude of consequences) memiliki hubungan positif dengan: (a) ethical recognition, (b) ethical judgment, (c) ethical intention.

H4: Konsensus Sosial (Social Consencus) memiliki hubungan positif dengan: (a) ethical recognition, (b) ethical judgment, (c) ethical intention.

H5: Probabilitas Efek (Probability of Effect) memiliki hubungan positif dengan: (a) ethical recognition, (b) ethical judgment, (c) ethical intention.

H6: Kesegeraan temporal (Temporal Immediacy) memiliki hubungan positif dengan: (a) ethical recognition, (b) ethical judgment, (c) ethical intention.

H7: Efek Konsentrasi (Concentration of Effect) memiliki hubungan positif dengan: (a) ethical recognition, (b) ethical judgment, (c) ethical intention.

H8: Kedekatan (Proximity)memiliki hubungan positif dengan: (a) ethical recognition, (b) ethical judgment, (c) ethical intention.

\section{Tingkat Pendidikan, Usia dan Gender}

Rest et al. (1986) menyatakan bahwa tingkat pendidikan dan usia dapat memengaruhi peningkatan Cognitive Moral Development (CMD) individu. Peningkatan cognitive moral akan berdampak pada peningkatan kemampuan seorang individu dalam mempertimbangkan isu moral yang selanjutnya berdampak pada keputusan etis yang dibuatnya (Kohlberg, 1976). Senada, McPhail dan Walters (2009) menyatakan pula bahwa bentuk yang berbeda dari tingkat pendidikan dapat berkontribusi terhadap level kematangan etika yang berbeda.

O'Fallon and Butterfield (2005) menemukan bahwa tingkat pendidikan berpengaruh positif dan signifikan terhadap pembuatan keputusan etis (ethical decision making). Namun, hasil berbeda ditemukan oleh Cagle and Baucus (2006) yang menyatakan bahwa tingkat pendidikan tidak berhubungan signifikan terhadap pengambilan keputusan etis. Perbedaan yang ditemukan oleh masingmasing peneliti tersebut, menjadi alasan penulis untuk menguji dan mengkonfirmasi pengaruh tingkat pendidikan terhadap pengambilan keputusan etis.

Riset mengenai perkembangan moral kognitif menemukan bahwa penalaran moral juga dipengaruhi oleh usia, karena usia memengaruhi moral maturity seseorang (McPhail dan Walters, 2009). Teori CMD oleh Kohlberg (1976) menyugestikan bahwa terdapat dampak posittif dari usia terhadap perkembangan moral, individu secara umumnya akan berpindah dari tahapan yang rendah atas penalaran moral ke tahapan yang lebih tinggi. Sehingga diekspektasikan individu yang lebih tua akan menunjukkan perilaku yang menjunjung nilainilai etis dibandingkan individu yang lebih muda. Namun berdasarkan histori literatur, ternyata hubungan antara usia dan pengambilan keputusan etis menghasilkan temuan yang belum konsisten (Musbah, 2010). Dengan demikian, variabel usia menarik untuk tetap diteliti bagiamana hubungannya dengan proses pengambilan keputusan etis.

Selanjutnya untuk variabel gender, seperti yang telah dijelaskan sepintas di bagian pendahuluan, telah terdapat banyak bukti empiris yang mengarahkan pada suatu simpulan bahwa wanita lebih etis dibandingkan pria. Hal tersebut dikarenakan sesuai dengan teori sosialisasi gender, pria lebih fokus pada pencapaian kesuksesan sehingga cenderung untuk mengabaikan dan melanggar aturan sehingga akan terlibat pada suatu tindakan yang tidak etis. Di lain sisi, wanita lebih fokus pada penyelesaian tugas mereka dengan baik serta menjaga harmoni di tempat kerja sehingga mereka cenderug untuk tidak melanggar aturan dan lebih sedikit dalam terlibat pada suatu tindakan yang tidak etis (Guffey dan McCartney, 2007). Namun demikian, masih tetap diperlukan penginvestigasian terkait hal ini karena masih ditemukan banyak temuan yang tidak konsisten, selain itu fenomenanya saat ini wanita telah banyak menca- 
pai posisi tinggi di level manajerial sehingga merupakan hal yang penting untuk memahami perbedaan gender dalam proses pengambilan keputusan etis (Musbah, 2010). Berdasarkan pemaparan tersebut, maka peneliti mengajukan hipotesis:

H9: Nilai rata-rata (a) ethical recognition, (b) ethical judgment, (c) ethical intention akan secara signifikan lebih besar untuk mahasiswa pascasarjana (tingkat pendidikan lebih tinggi) dibandingkan mahasiswa sarjana.

H10: Nilai rata-rata (a) ethical recognition, (b) ethical judgment, (c) ethical intention akan secara signifikan lebih besar untuk mahasiswa wanita dibandingkan pria.

H11: Nilai rata-rata (a) ethical recognition, (b) ethical judgment, (c) ethical intention akan secara signifikan lebih besar semakin meningkatnya usia mahasiswa.

\section{METODE PENELITIAN}

Penelitian ini menggunakan penelitian kuantitatif dengan teknik pengumpulan data survey dengan memberikan kuesioner jenis tertutup kepada responden. Dalam setiap kuesioner, akan terdapat tiga bagian. Bagian pertama berisi keterangan singkat demografi responden, bagian kedua berisi pertanyaan filosofi moral personal dan yang ketiga terdiri dari dua skenario mengenai pengambilan keputusan etis dalam ranah akuntansi serta respon pernyataan untuk intensitas moral.

\section{Pengumpulan Data}

Sampel penelitian ini adalah mahasiswa sarjana dan pascasarjana yang ada di salah satu univer- sitas yang masing-masing berada di Kota Surabaya dan Yogyakarta. Subjek penelitian yang merupakan mahasiswa akuntansi ini digunakan untuk menilai bagaimana pengambilan keputusan etis mereka karena mereka diekspektasikan akan menjadi akuntan di masa depan (Musbah, 2010). Kriteria sampel penelitian ini adalah subjek telah lulus atau sedang mengambil mata kuliah bertemakan etika bisnis dan profesi. Dengan demikian, pertimbangan dipilihnya dua universitas tersebut sebagai sampel penelitian ini adalah dalam hal diajarkannya mata kuliah etika bisnis dengan materi yang tidak jauh berbeda satu sama lain serta sesuai dengan submateri yang ingin diteliti, yakni terkait pengambilan keputusan etis. Kriteria tersebut juga telah digunakan di beberapa penelitian sebelumnya (Cagle dan Baucus, 2006; Chan dan Leung, 2006; Musbah, 2010) .

Data dikumpulkan dengan menggunakan metode survey. Metode ini memiliki kelebihan dalam hal validitas eksternalnya yang tinggi, yakni kemampuan hasil suatu penelitian dalam digeneralisasi (Ghozali, 2009; Ertambang dan Utami, 2015). Prosedur penyebaran kuesioner dilakukan dengan menyebarkan kuesioner setiap ada sesi perkuliahan yang sedang berlangsung dan kemudian meminta partisipan untuk langsung mengisinya dan setelah itu dikembalikan langsung kepada peneliti. Prosedur tersebut selain praktis, juga dapat mencegah terjadinya non reponse bias. Selain itu, untuk mencegah adanya bias respon yang terjadi, salah satunya adalah dengan meminta data demografi responden yang tidak terlalu lengkap atau hanya sesuai dengan kebutuhan penelitian, dengan kata lain responden tidak perlu merasa khawatir bila kejujurannya diketahui oleh

$$
\begin{aligned}
& \text { Faktor Internal } \\
& \text { - Filosofi Moral Personal } \\
& \text { - Tingkat Pendidikan } \\
& \text { - Usia } \\
& \text { - Gender }
\end{aligned}
$$

\footnotetext{
Faktor Eksternal (Intensitas Moral)

- Besaran Konsekuensi

- Konsensus Sosial

- Probabilitas Efek

- Kesegeraan Temporal

- Efek Konsentrasi

- Kedekatan
}

Proses Pengambilan Keputusan Etis

- Ethical Recognition

- EthicalJudgment

- Ethical Intention

\section{Gambar 1. Model Penelitian}


pihak penyelenggara penelitian. Total kuesioner yang disebarkan kepada subjek penelitian adalah 197 kuesioner. Kuesioner yang dapat diolah lebih lanjut untuk pengujian statistik adalah 173 kuesioner dan sisanya sebanyak 54 kuesioner tidak dapat diolah lebih lanjut. Alasan tidak digunakannya 54 kuesioner tersebut adalah karena dua alasan, pertama responden tidak mengisi secara lengkap atas butir-butir pernyataan kuesioner maupun isian mengenai informasi demografi. Kedua, terdapat pula beberapa beberapa responden yang tampaknya tidak serius dalam mengisi jawaban kuesioner. Hal tersebut diperlihatkan dengan adanya kecenderunga pemilihan jawaban dengan skala yang sama.

\section{Pengukuran Variabel}

Variabel independen dalam penelitian ini adalah: (1) idealisme, (2) relativisme, (3) besaran konsekuensi, (4) konsensus sosial, (5) kesegeraan temporal, (6) tingkat pendidikan, (7) usia, (8) gender. Sedangkan variabel dependen adalah (1) ethical recognition, (2) ethical judgment, dan (3) ethical intention. Adapun yang dimaksud dengan variabel idealisme adalah sejauh mana individu berfokus pada kebenaran yang melekat atau kesalahan dari tindakan terlepas dari hasil tindakan tersebut. Relativisme adalah sejauh mana individu menolak aturan atau standar moral yang universal. Besaran konsekuensi (magnitude of consequences) didefinisikan sebagai jumlah kerugian (manfaat) yang dihasilkan oleh pengorbanan (kebermanfaatan) dari sebuah tindakan etis.

Konsensus sosial adalah tingkat kesepakatan sosial bahwa sebuah tindakan dianggap sebagai tindakan yang baik atau buruk. Probabilitas efek adalah kemungkinan sebuah tindakan akan menyebabkan kerugian dengan segera di masa yang akan datang. Kesegeraan temporal adalah jarak atau waktu antara pada saat terjadi dan awal mula konsekuensi dari sebuah tindakan etis tertentu. Efek konsentrasi adalah jumlah orang yang memengaruhi dan dipengaruhi oleh sebuah tindakan yang dilakukan. Terakhir kedekatan adalah perasaan kedekatan (sosial, budaya, psikologi, atau fisik) yang dimiliki oleh pembawa moral (moral agent) untuk si pelaku dari kejahatan (kemanfaatan) dari suatu tindakan tertentu.

Ethical recognition diukur dengan menyatakan tingkat persetujuan dari pernyataan apakah situasi yang ada di skenario melibatkan problema etika atau tidak, selanjutnya ethical judgment diukur dengan menyatakan tingkat persetujuan apakah aktor yang terlibat dalam situasi yang ada di skenario seharusnya tidak melakukan tindakan tersebut. Terakhir,ethical intention diukur dengan menyatakan tingkat persetujuan responden untuk tidak melakukan tindakan serupa seperti tindakan yang ada dalam skenario.Untuk variabel tingkat pendidikan diukur lewat jenjang pendidikan yang sedang ditempuh oleh responden yang mana didikotomuskan menjadi dua yaitu jenjang sarjana dan pascasarjana.

Kuesioner filosofi moral personal (ethics position) diambil dari instrumen yang telah dibuat oleh Forsyth (1980) yang mengukur dimensi idealisme dan relativisme dengan masing-masing memiliki 10 pernyataan. Skenario pada kuesioner ini menggunakan skenario yang dibuat oleh Institute of Management Accountantsdan telah diabstraksikan oleh Flory, et al. (1992) yang mana secara originalnya memiliki empat skenario dengan masing-masing memiliki sembilan pertanyaan. Rincian skenario tersebut adalah: (1) Skenario pertama $=$ menyetujui pelaporan biaya yang dipertanyakan; (2) Skenario kedua = manipulasi pembukuan perusahaan; (3) Skenario ketiga= melanggar kebijakan perusahaan; (4) Skenario keempat= memperpanjang kredit yang diragukan. Skenario yang digunakan pada penelitian ini adalah skenario kedua dan keempat. Keempat skenario tersebut secara umumnya akan ditemukan pada dunia kerja dan memiliki tingkat ketidaketisan yang bervariasi (Leitsch, 2004).

Skenario kedua (manipulasi pembukuan perusahaan) mewakili isu akuntansi yang memiliki tingkat tidak etis lebih tinggi dibandingkan dengan skenario keempat (memperpanjang kredit yang diragukan). Oleh karenanya, skenario yang digunakan pada penelitian ini hanya dua skenario, yakni skenario tentang manipulasi pembukuan perusahaan dan memperpanjang kredit yang diragukan. Peneliti mengambil masing-masing satu skenario untuk mewakili masing-masing kategori berdasarkan tingkat ketidaketisan isu tersebut. Sehingga alasan lain untuk mencegah kejenuhan partisipan dalam mengisi kuesioner dapat tepenuhi. Pernyataan pada masing-masing skenarioadalah sebanyak sembilan pernyataan sesuaitujuan penelitian, yakni dengan rincian tiga pernyataan mengukur tiga tahapan proses pengambilan keputusan etis, dan enam pertanyaan mengukur enam variabel intensitas moral. Seluruh pernyataan dalam kuesioner penelitian ini disajikan dengan skala likert berdasarkan peringkat dari 1 (menyatakan tidak setuju) sampai 5 (menyatakan sangat setuju). 


\section{Teknik Analis Data}

Metode analisis data menggunakan regresi linear hirarki untuk menguji hubungan antara variabel idealisme, relativisme, intensitas moral terhadap tiga tahapan proses pengambilan keputusan etis di skenario satu dan skenario dua. Alasan digunakannya regresi linear hirarki adalah karena penelitian ini bertujuan untuk melihat dampak dari beberapa faktor (variabel individual dan intensitas moral) terhadap pengambilan keputusan etis. Secara teoretis, variabel penting dimasukkan terlebih dahulu ke dalam model, yakni dua komponen dari filosofi moral personal (idealisme dan relativisme), baru kemudian komponen dari intensitas moral dimasukkan di model. Beberapa penelitian sebelumnya juga menggunakan langkah pemasukan variabel seperti yang dijelaskan tersebut (Dubinsky et al., 2004; Musbah, 2010; Sweeney dan Costello, 2009).

Independent t-test dan Anova one-way digunakan untuk menguji ada atau tidaknya perbedaan nilai ethical recognition, ethical judgment, dan ethical intention berdasarkan tingkat pendidikan, usia, dan gender yang mana merupakan variabel kategorikal. Sebelum keseluruhan hal tersebut dilakukan, uji validitas dan reliabilitas dilakukan terlebih dahulu. Uji validitas dilakukan dengan menggunakan uji pearson-correlation dengan skor minimal 0,3 dan uji reliabilitas dilakukan dengan melihat skor cronbach alpha dengan skor minimal 0,6 .

\section{HASIL DAN PEMBAHASAN}

\section{Demografi dan Statistik Deskriptif}

Uji reliabilitas dan validitas menunjukkan hasil bahwa seluruh item pertanyaan untuk variabel idealisme dan relativisme telah reliabel dan valid (cronbach alpha> 0,6 dan korelasi pearson >0,3), kecuali untuk item pertanyaan nomor sembilan pada variabel idealisme dan item pertanyaan nomor tujuh pada variabel relativisme karena skor cronbach's alpha if item deleted lebih dari skor cronbach's alpha dari masing-masing variabel bersangkutan. Sehingga kedua item pertanyaan tersebut tidak diikutsertakan sebagai komposit dari variabel idealisme dan relativisme dalam pengujian hipotesis selanjutnya. Selain itu juga tidak terjadi multikolenieritas antara variabel independen dengan skor VIF seluruhnya di bawah 10 (Ghozali, 2009).

Tabel 1 menunjukkan ringkasan demografi responden. Informasi tambahan untuk tabel di atas adalah, dari 52 responden yang berjenis kelamin laki-laki, 20 adalah mahasiswa sarjana dan 32 adalah mahasiswa pascasarjana. Selanjutnya dari 121 responden yang berjenis kelamin perempuan, 45 adalah mahasiswa sarjana dan 76 adalah mahasiswa pascasarjana. Sebagian besar responden, yakni 82\% (142 responden), memiliki usia di rentang 20 hingga 25 tahun, yakni keseluruhan 65 responden mahasiswa sarjana serta 77 adalah mahasiswa pascasarjana. Sebaran usia dari mahasiswa pascasarjana selanjutnya adalah sebanyak 20 responden memiliki usia di rentang 26-30 tahun, tujuh responden memiliki usia di rentang 30-35 tahun, dan hanya empat responden yang berusia lebih dari 35 tahun. Selanjutnya, Tabel 2 di bawah ini menyajikan penjelasan deskriptif statistik dari masing-masing variabel pada penelitian ini.

\section{Hubungan Filosofi Moral Personal dan Intensitas Moral terhadapEthical Recognition}

Hubungan antara filosofi moral personal dan ethical recognition diinvestigasi dengan menguji dua hipotesis yakni terkait hubungannya dengan idealisme (H1a) dan relativisme (H2a). Untuk variabel idealisme, pada kelompok mahasiswa sarjana, dari Tabel 3 dapat disimpulkan bahwa idealisme memiliki hubungan positif signifikan ( $\beta=$ $0,32 ; p<0,01)$ dengan ethical recognition namun hanya pada skenario pertama.

Sedangkan untuk kelompok mahasiswa pascasarjana, idealisme memiliki hubungan positif signifikan $(\beta=0,20 ; \quad p<0,05) \quad$ dengan ethical recognition namun hanya pada skenario pertama. Sehingga dengan demikian, H1a terdukung parsial untuk kedua kelompok sampel.

Tabel 1. Demografi Responden

\begin{tabular}{lccccccc}
\hline \multicolumn{2}{c}{ Tingkat Pendidikan } & \multicolumn{3}{c}{ Jenis Kelamin } \\
\hline Sarjana & 65 & Pria & 52 & $20-25$ tahun & 142 & $30-35$ tahun & 7 \\
Pascasarjana & 108 & Wanita & 121 & $26-30$ tahun & 20 & $>35$ tahun & 4 \\
\hline \multicolumn{4}{c}{ Total Responden: 173} \\
\hline
\end{tabular}


Tabel 2. Statistik Deskriptif Variabel Penelitian

\begin{tabular}{|c|c|c|c|c|}
\hline Variabel & Min & Mak & Rerata & Deviasi Standar \\
\hline Idealisme & 3,00 & 5,00 & 3,98 & 0,47 \\
\hline Relativsme & 1,67 & 4,56 & 3,45 & 0,53 \\
\hline Besaran Konsekuensi (Skenario 1) & 1,00 & 5,00 & 3,56 & 0,82 \\
\hline Konsensus Sosial (Skenario 1) & 1,00 & 5,00 & 3,83 & 0,83 \\
\hline Probabilitas Efek (Skenario 1) & 1,00 & 5,00 & 3,28 & 0,96 \\
\hline Kesegeraan Temporal (Skenario (1) & 1,00 & 5,00 & 3,43 & 0,94 \\
\hline Konsentrasi Efek (Skenario 1) & 1,00 & 5,00 & 3,35 & 1,04 \\
\hline Kedekatan (Skenario 1) & 1,00 & 5,00 & 3,88 & 0,67 \\
\hline Besaran Konsekuensi (Skenario 2) & 1,00 & 5,00 & 3,30 & 0,94 \\
\hline Konsensus Sosial (Skenario 2) & 2,00 & 5,00 & 3,43 & 0,96 \\
\hline Probabilitas Efek (Skenario 2) & 1,00 & 5,00 & 3,27 & 0,92 \\
\hline Kesegeraan Temporal (Skenario (2) & 1,00 & 5,00 & 3,22 & 0,98 \\
\hline Konsentrasi Efek (Skenario 2) & 1,00 & 5,00 & 3,15 & 0,99 \\
\hline Kedekatan (Skenario 2) & 1,00 & 5,00 & 3,87 & 0,67 \\
\hline Ethical Recognition (Skenario1) & 2,00 & 5,00 & 4,13 & 0,59 \\
\hline Ethical Recognition (Skenario 2) & 1,00 & 5,00 & 3,93 & 0,72 \\
\hline Ethical Judgment (Skenario 1) & 2,00 & 5,00 & 3,80 & 0,77 \\
\hline Ethical Judgment (Skenario 2) & 2,00 & 5,00 & 3,50 & 0,86 \\
\hline Ethical Intention (Skenario 1) & 1,00 & 5,00 & 3,53 & 0,98 \\
\hline Ethical Intention (Skenario 2) & 1,00 & 5,00 & 3,34 & 0,91 \\
\hline
\end{tabular}

Selanjutnya untuk variabel relativisme, pada kelompok mahasiswa sarjana terlihat bahwa tidak ditemukan hubungan signifikan baik di skenario pertama maupun kedua. Selanjutnya, pada kelompok mahasiswa pascasarjana, relativisme ditemukan memiliki hubungan negatif signifikan $(\boldsymbol{\beta}=-0,21$, $\mathrm{p}<0,05)$ dengan ethical recognition namun hanya untuk skenario pertama. Dengan demikian H2a tidak terdukung untuk kelompok mahasiswa sarjana, dan H2a terdukung parsial untuk kelompok mahasiswa pascasarjana. Berpindah ke faktor intensitas moral, untuk variabel besaran konsekuensi tidak ditemukan hubungan signifikan dengan ethical recognition baik untuk kelompok mahasiswa sarjana dan pascasarjana. Variabel konsensus sosial memiliki hubungan positif signifikan $(\beta=0,33 ; \quad \mathrm{p}<0,1)$ untuk kelompok mahasiswa sarjana di skenario kedua, serta juga memiliki hubungan positif signifikan untuk kelompok mahasiswa pascasarjana baik di skenario pertama $(\beta=$ $0,21 ; \mathrm{p}<0,05)$ maupun kedua $(\beta=0,29 ; \mathrm{p}<0,01)$.

Variabel probabilitas efek memiliki hubungan negatif signifikan dengan ethical recognition di kedua skenario untuk kelompok mahasiswa sarjana $(\beta=-0,49 ; \quad \mathrm{p}<0,05$ dan $\beta=-0,24, \quad \mathrm{p}<0,1)$. Meskipun hubungan yang ditemukan signifikan namun tidak sesuai dengan arah prediksi yang seharusnya. Sedangkan untuk kelompok mahasiswa pascasarjana, probabilitas efek tidak memiliki hubungan signifikan dengan ethical recogntion di kedua skenario. Variabel kesegeraan temporal memiliki hubungan positif signifikan $(\beta=0,22$; $\mathrm{p}<0,1)$ untuk kelompok mahasiswa sarjana di skenario dua saja, dan tidak memiliki hubungan signifikan untuk kelompok mahasiswa pascasarjana di kedua skenario.

Variabel konsentrasi efek memiliki hubungan positif signifikan $(\beta=0,25 ; \mathrm{p}<0,05)$ dengan ethical recognition untuk kelompok mahasiswa sarjana di skenario pertama, dan tidak memiliki hubungan signifikan untuk kelompok mahasiswa pascasarjana di kedua skenario. Variabel kedekatan memiliki hubungan negatif signifikan $(\beta=0,27 ; \quad \mathrm{p}<0,05)$ namun dengan arah yang berlawanan sesuai prediksi untuk kelompok mahasiswa sarjana di skenario pertama, dan tidak memiliki hubungan signifikan untuk kelompok mahasiswa pascasarjana.

Dengan demikian disimpulkan, H3a tidak terdukung di kedua kelompok sampel, H4a terdukung untuk kelompok mahasiswa pascasarjana, dan terdukung parsial untuk kelompok mahasiswa sarjana, H5a tidak terdukung untuk kedua kelompok sampel, H6a terdukung parsial untuk kelompok mahasiswa sarjana dan tidak terdukung untuk kelompok mahasiswa pascasarjana, H7a terdukung parsial untuk kelompok mahasiswa sarjana dan tidak terdukung untuk kelompok mahasiswa pascasarjana, H8a tidak terdukung untuk kedua kelompok sampel. 
Tabel 3. Hasil Regresi Hirarki atas Variabel Ethical Recognition

\begin{tabular}{|c|c|c|c|c|c|c|c|}
\hline \multicolumn{8}{|c|}{ Mahasiswa Sarjana } \\
\hline \multirow{2}{*}{\multicolumn{2}{|c|}{ Variabel dan Skenario }} & \multicolumn{3}{|c|}{$\begin{array}{c}\text { Skenario } 1 \\
\text { (Manipulasi Laporan } \\
\text { Keuangan) } \\
\end{array}$} & \multicolumn{3}{|c|}{$\begin{array}{c}\text { Skenario } 2 \\
\text { (Memperpanjang Kredit yang } \\
\text { Diragukan) }\end{array}$} \\
\hline & & B & St.E & $\beta$ & B & St.E & $\beta$ \\
\hline \multirow[t]{3}{*}{ Model 1} & Idealisme & 0,58 & 0,14 & $0,48^{* * *}$ & $-0,14$ & 0,17 & $-0,09$ \\
\hline & Relativisme & $-0,01$ & 0,16 & $-(0,01$ & $-0,27$ & 0,20 & $-0,16$ \\
\hline & $\mathrm{R}^{2}(\mathrm{~F})$ & \multicolumn{3}{|c|}{$0,23\left(9,21^{* * *}\right)$} & \multicolumn{3}{|c|}{$0,04(1,16)$} \\
\hline \multirow[t]{10}{*}{ Model 2} & Idealisme & 0,36 & 0,13 & $0,32^{* * *}$ & $-(0,101$ & 0,18 & $-(0,07$ \\
\hline & Relativisme & 0,05 & 0,14 & 0,04 & $-0,31$ & 0,20 & $-0,19$ \\
\hline & Besaran Konsekuensi & 0,09 & 0,15 & 0,09 & $-0,08$ & 0,10 & $-0,11$ \\
\hline & Konsensus Sosial & 0,07 & 0,07 & 0,11 & 0,23 & 0,08 & $0,33^{*}$ \\
\hline & Probabilitas Efek & $-0,48$ & 0,15 & $-0,49^{* *}$ & $-0,19$ & 0,10 & $-0,24^{*}$ \\
\hline & Kesegeraan Temporal & 0,10 & 0,08 & 0,13 & 0,15 & 0,08 & $0,22^{*}$ \\
\hline & Konsentrasi Efek & 0,22 & 0,09 & $0,26^{* *}$ & $-0,01$ & 0,10 & $-0,02$ \\
\hline & Kedekatan & $-0,30$ & $-0,26$ & $-0,27^{* *}$ & $-0,18$ & 0,14 & $-0,16$ \\
\hline & $\mathrm{R}^{2}(\mathrm{~F})$ & \multicolumn{3}{|c|}{$0,45\left(5,94^{* * *}\right)$} & \multicolumn{3}{|c|}{$0,23\left(2,12^{* *}\right)$} \\
\hline & $\Delta \mathrm{R}^{2}(\Delta \mathrm{F})$ & \multicolumn{3}{|c|}{$0,23\left(3,97^{* * *}\right)$} & \multicolumn{3}{|c|}{$0,19\left(2,34^{* *}\right)$} \\
\hline \multicolumn{8}{|c|}{ Mahasiswa Pascasarjana } \\
\hline \multirow{2}{*}{\multicolumn{2}{|c|}{ Variabel dan Skenario }} & \multicolumn{3}{|c|}{$\begin{array}{c}\text { Skenario 1 } \\
\text { (Manipulasi Laporan } \\
\text { Keuangan) }\end{array}$} & \multicolumn{3}{|c|}{$\begin{array}{c}\text { Skenario } 2 \\
\text { (Memperpanjang Kredit yang } \\
\text { Diragukan) }\end{array}$} \\
\hline & & B & St.E & $\beta$ & B & St.E & $\beta$ \\
\hline \multirow[t]{3}{*}{ Model 1} & Idealisme & 0,27 & 0,14 & $0,18^{*}$ & 0,52 & 0,17 & $0,28 * * *$ \\
\hline & Relativisme & $-0,24$ & 0,11 & $-0,21^{* *}$ & $-0,04$ & 0,13 & $-0,03$ \\
\hline & $\mathrm{R}^{2}(\mathrm{~F})$ & \multicolumn{3}{|c|}{$0,07\left(4,31^{* *}\right)$} & \multicolumn{3}{|c|}{$0,08\left(4,39^{* *}\right)$} \\
\hline \multirow[t]{10}{*}{ Model 2} & Idealisme & 0,15 & 0,15 & 0,10 & 0,39 & 0,18 & $0,20 * *$ \\
\hline & Relativisme & $-0,23$ & 0,11 & $-0,21$ * * & $-0,03$ & 0,13 & $-0,02$ \\
\hline & Besaran Konsekuensi & 0,02 & 0,08 & 0,02 & 0,08 & 0,09 & 0,10 \\
\hline & Konsensus Sosial & 0,15 & 0,07 & $0,21^{* *}$ & 0,23 & 0,08 & $0,29 * * *$ \\
\hline & Probabilitas Efek & $-0,02$ & 0,07 & $-(0,04$ & 0,06 & 0,10 & 0,07 \\
\hline & Kesegeraan Temporal & 0,05 & 0,07 & 0,08 & 0,07 & 0,09 & 0,09 \\
\hline & Konsentrasi Efek & 0,05 & 0,06 & 0,09 & 0,00 & 0,09 & 0,00 \\
\hline & Kedekatan & 0,11 & 0,09 & 0,13 & 0,07 & 0,11 & 0,06 \\
\hline & $\mathrm{R}^{2}(\mathrm{~F})$ & \multicolumn{3}{|c|}{$0,18\left(2,73^{* * *}\right)$} & \multicolumn{3}{|c|}{$0,22\left(3,42^{* * *}\right)$} \\
\hline & $\Delta \mathrm{R}^{2}(\Delta \mathrm{F})$ & \multicolumn{3}{|c|}{$0,11\left(2,11^{*}\right)$} & \multicolumn{3}{|c|}{$0,14\left(2,93^{* *}\right)$} \\
\hline
\end{tabular}

${ }^{* * *} \mathrm{p}<0,01 ;{ }^{*} \mathrm{p}<0,05 ;{ }^{*} \mathrm{p}<0,1$

\section{Hubungan Filosofi Moral Personal dan Intensitas Moral terhadap EthicalJudgment}

Hubungan antara filosofi moral personal dan ethical judgment juga diinvestigasi dengan menguji dua hipotesis, yakni terkait hubungannya dengan idealisme (H1b) dan relativisme (H2b). Untuk idealisme pada kelompok mahasiswa sarjana, ditemukan hubungan positif signifikan $(\beta=0,30$; $\mathrm{p}<0,05)$ dengan ethical judgment namun hanya pada skenario pertama. Sedangkan untuk kelompok mahasiswa pascasarjana, idealisme memiliki hubungan positif signifikan $(\beta=0,20 ; \mathrm{p}<0,05$ dan $\beta=0,16 ; \mathrm{p}<0,05)$ dengan ethical judgment di kedua skenario. Dengan demikian, H1b terdukung untuk kelompok mahasiswa pascasarjana dan terdukung parsial untuk kelompok mahasiswa sarjana.
Selanjutnya, untuk variabel relativisme, pada kelompok mahasiswa sarjana terdapat hubungan negatif signifikan hanya di skenario pertama $(\beta=$ $0,24 ; p<0,1)$. Lalu pada kelompok mahasiswa pascasarjana, relativisme tidak memiliki hubungan negatif signifikan. Dengan demikian $\mathrm{H} 2 \mathrm{~b}$ terdukung parsial untuk kelompok mahasiswa sarjana dan tidak terdukung untuk kelompok mahasiswa pascasarjana.

Berpindah ke faktor intensitas moral, untuk variabel besaran konsekuensi ditemukan hubungan positif signifikan dengan ethical judgment untuk kelompok mahasiswa sarjana di skenario pertama $(\beta=0,33 ; \mathrm{p}<0,1)$ sedangkan untuk kelompok mahasiswa sarjana tidak ditemukan hubungan signifikan. Variabel konsensus sosial memiliki hubungan positif signifikan $(\beta=0,26$; $\mathrm{p}<0,1)$ untuk kelo- 
Tabel 4. Hasil Regresi Hirarkiatas Variabel Ethical Judgment

\begin{tabular}{|c|c|c|c|c|c|c|c|}
\hline \multicolumn{8}{|c|}{ Mahasiswa Sarjana } \\
\hline \multicolumn{2}{|c|}{ Variabel dan Skenario } & \multicolumn{3}{|c|}{$\begin{array}{c}\text { Skenario 1 } \\
\text { (Manipulasi Laporan Keuangan) }\end{array}$} & \multicolumn{3}{|c|}{$\begin{array}{c}\text { Skenario } 2 \\
\text { (Memperpanjang Kredit yang } \\
\text { Diragukan) }\end{array}$} \\
\hline & & $\mathbf{B}$ & St.E & $\beta$ & B & St.E & $\beta$ \\
\hline \multirow{3}{*}{ Model 1} & Idealisme & 0,60 & 0,22 & $0,32^{* * *}$ & 0,03 & 0,26 & 0,01 \\
\hline & Relativisme & $-0,47$ & 0,26 & $-0,21^{*}$ & $-0,31$ & 0,30 & $-0,13$ \\
\hline & $\mathbf{R}^{2}(\mathbf{F})$ & \multicolumn{3}{|c|}{$0,14\left(5,22^{* *}\right)$} & \multicolumn{3}{|c|}{$0,02(0,55)$} \\
\hline \multirow{10}{*}{ Model 2} & Idealisme & 0,58 & 0,25 & $0,30^{* *}$ & 0,00 & 0,28 & 0,00 \\
\hline & Relativisme & $-0,52$ & 0,28 & $-0,24^{*}$ & $-0,28$ & 0,30 & $-0,12$ \\
\hline & Besaran Konsekuensi & 0,54 & 0,29 & $0,33^{*}$ & 0,09 & 0,15 & 0,08 \\
\hline & Konsensus Sosial & 0,16 & 0,14 & 0,15 & 0,25 & 0,13 & $0,26^{*}$ \\
\hline & Probabilitas Efek & $-0,32$ & 0,29 & $-0,20$ & $-0,20$ & 0,16 & $-0,17$ \\
\hline & Kesegeraan Temporal & $-0,02$ & 0,16 & $-0,02$ & 0,09 & 0,13 & 0,10 \\
\hline & Konsentrasi Efek & $-0,05$ & 0,17 & $-0,03$ & 0,20 & 0,12 & 0,19 \\
\hline & Kedekatan & $-0,15$ & 0,22 & $-0,09$ & 0,08 & 0,21 & 0,05 \\
\hline & $\mathbf{R}^{2}(\mathbf{F})$ & \multicolumn{3}{|c|}{$0,21\left(1,88^{*}\right)$} & \multicolumn{3}{|c|}{$0,17(1,44)$} \\
\hline & $\Delta \mathrm{R}^{2}(\Delta \mathrm{F})$ & \multicolumn{3}{|c|}{$0,07(0,80)$} & \multicolumn{3}{|c|}{$0,15(1,72)$} \\
\hline \multicolumn{8}{|c|}{ Mahasiswa Pascasarjana } \\
\hline \multirow{2}{*}{\multicolumn{2}{|c|}{ Variabel dan Skenario }} & \multicolumn{3}{|c|}{$\begin{array}{c}\text { Skenario 1 } \\
\text { (Manipulasi Laporan Keuangan) }\end{array}$} & \multicolumn{3}{|c|}{$\begin{array}{c}\text { Skenario 2 } \\
\text { (Memperpanjang Kredit yang } \\
\text { Diragukan) }\end{array}$} \\
\hline & & $\mathbf{B}$ & St.E & $\beta$ & B & St.E & $\beta$ \\
\hline \multirow{6}{*}{ Model 1} & Idealisme & 0,44 & 0,14 & 0,30 *** & 0,58 & 0,17 & $0,32^{* * *}$ \\
\hline & Relativisme & $-(0,20$ & 0,10 & $-0,19^{* *}$ & $-(0,00$ & 0,13 & $-(0,00$ \\
\hline & $\mathrm{R}^{2}(\mathrm{~F})$ & \multicolumn{3}{|c|}{$0,12\left(7,12^{* * *}\right)$} & \multicolumn{3}{|c|}{$0,10\left(5,93^{* * *}\right)$} \\
\hline & Idealisme & 0,30 & 0,14 & $0,20^{* *}$ & 0,30 & 0,15 & $0,16^{* *}$ \\
\hline & Relativisme & $-0,14$ & 0,11 & $-0,13$ & $-0,05$ & 0,11 & $-0,03$ \\
\hline & Besaran Konsekuensi & 0,00 & 0,08 & 0,01 & 0,04 & 0,07 & 0,05 \\
\hline \multirow{7}{*}{ Model 2} & Konsensus Sosial & 0,22 & 0,07 & $0,30 * * *$ & 0,44 & 0,07 & $0,55^{* * *}$ \\
\hline & Probabilitas Efek & $-0,03$ & 0,07 & $-0,04$ & 0,06 & 0,08 & 0,08 \\
\hline & Kesegeraan Temporal & 0,00 & 0,06 & 0,01 & 0,05 & 0,08 & 0,07 \\
\hline & Konsentrasi Efek & 0,09 & 0,06 & 0,17 & 0,02 & 0,07 & 0,03 \\
\hline & Kedekatan & $-0,03$ & 0,08 & $-0,03$ & 0,15 & 0,09 & $0,14^{*}$ \\
\hline & $\mathrm{R}^{2}(\mathrm{~F})$ & \multicolumn{3}{|c|}{$0,23\left(3,76^{* * *}\right)$} & \multicolumn{3}{|c|}{$0,48\left(11,19^{* * *}\right)$} \\
\hline & $\Delta \mathrm{R}^{2}(\Delta \mathrm{F})$ & \multicolumn{3}{|c|}{$0,11\left(2,45^{* *}\right)$} & \multicolumn{3}{|c|}{$0,37\left(11,73^{* * *}\right)$} \\
\hline
\end{tabular}

${ }^{*}{ }^{*} \mathrm{p}<0,01 ;{ }^{*}{ }^{*} \mathrm{p}<0,05 ;{ }^{*} \mathrm{p}<0,1$

mpok mahasiswa sarjana di skenario kedua, serta juga memiliki hubungan positif signifikan untuk kelompok mahasiswa pascasarjana baik di skenario pertama $(\beta=0,3 ; p<0,01)$ maupun kedua $(\beta=0,55$; $\mathrm{p}<0,01)$. Kemudian, berturut-turut untuk variabel probabilitas efek, kesegeraan temporal, dan konsentrasi efek tidak ditemukan hubungan signifikan untuk kedua kelompok mahasiswa baik di skenario pertama maupun kedua. Terakhir variabel kedekatan, ditemukan hubungan positif signifikan $(\beta=0,14 ; \quad \mathrm{p}<0,1)$ untuk kelompok mahasiswa pascasarjana di skenario kedua saja.

Dengan demikian disimpulkan, H3b terdukung parsial untuk kelompok mahasiswa sarjana dan tidak terdukung untuk kelompok mahasiswa pascasarjana, H4b terdukung untuk kelompok mahasiswa pascasarjana dan terdukung parsial untuk kelompok mahasiswa sarjana, berturut-turut
H5b, H6b, dan H7b tidak terdukung untuk kedua kelompok sampel, terakhir untuk H8b terdukung parsial untuk kelompok mahasiswa pascasarjana dan tidak terdukung untuk kelompok mahasiswa sarjana.

\section{Hubungan Filosofi Moral Personal dan Intensitas Moral terhadap Ethical Intention}

Hubungan antara filosofi moral personal dan ethical intention diinvestigasi dengan menguji dua hipotesis yakni terkait hubungannya dengan idealisme (H1c) dan relativisme (H2c). Untuk variabel idealisme, pada kelompok mahasiswa sarjana, Tabel 5 memperlihakan variabel tersebut tidak memiliki hubungan signifikan dengan ethical intention baik di skenario pertama maupun kedua. Sedangkan untuk kelompok mahasiswa pasca- 
sarjana terdapat hubungan positif signifikan antara idealisme dengan ethical intention $(\beta=0,24$; $\mathrm{p}<0,01)$ di skenario kedua. Dengan demikan, H1c terdukung parsial untuk kelompok mahasiswa pascasarjana dan tidak terdukung untuk kelompok mahasiswa sarjana.

Selanjutnya, untuk variabel relativisme, pada kelompok mahasiswa sarjana terlihat bahwa tidak ditemukan hubungan signifikan baik di skenario pertama maupun kedua. Lalu pada kelompok mahasiswa pascasarjana, relativisme ditemukan memiliki hubungan negatif signifikan $(\beta=-0,23$, $\mathrm{p}<0,05)$ namun hanya untuk skenario pertama. Sehingga H2c tidak terdukung untuk kelompok mahasiswa sarjana terdukung parsial untuk kelompok mahasiswa pascasarjana. Berpindah ke faktor intensitas moral, untuk variabel besaran konsekuensi tidak ditemukan hubungan signifikan dengan ethical intention. untuk kelompok mahasiswa sarjana baik pada skenario pertama maupun kedua.

Sedangkan untuk kelompok mahasiswa pascasarjana ditemukan hubungan positif signifikan di kedua skenario $(\beta=0,22 ; \mathrm{p}<0,05$ dan $\beta=0,40$; $\mathrm{p}<0,01)$. Variabel konsensus sosial tidak memiliki hubungan signifikan dengan ethical intention untuk kelompok mahasiswa sarjana baik pada skenario pertama maupun kedua. Sedangkan untuk kelompok mahasiswa pascasarjana ditemukan hubungan positif signifikan di skenario kedua skenario $(\beta=0,19 ; \mathrm{p}<0,05)$.

Variabel probabilitas efek tidak memiliki hubungan signifikan dengan ethical intention untuk

Tabel 5. Hasil Regresi Hirarkiatas Variabel Ethical Intention

\begin{tabular}{|c|c|c|c|c|c|c|c|}
\hline \multicolumn{8}{|c|}{ Mahasiswa Sarjana } \\
\hline \multirow{2}{*}{\multicolumn{2}{|c|}{ Variabel dan Skenario }} & \multicolumn{3}{|c|}{$\begin{array}{c}\text { Skenario 1 } \\
\text { (Manipulasi Laporan Keuangan) }\end{array}$} & \multicolumn{3}{|c|}{$\begin{array}{c}\text { Skenario 2 } \\
\text { (Memperpanjang Kredit yang } \\
\text { Diragukan) }\end{array}$} \\
\hline & & B & St.E & $\beta$ & B & St.E & $\beta$ \\
\hline \multirow{3}{*}{ Model 1} & Idealisme & $-(0,26$ & 0,27 & $-(0,12$ & 0,02 & 0,26 & 0,01 \\
\hline & Relativisme & 0,23 & 0,31 & 0,09 & $-(0,39$ & 0,30 & $-0,16$ \\
\hline & $\mathrm{R}^{2}(\mathrm{~F})$ & \multicolumn{3}{|c|}{$0,02(0,72)$} & \multicolumn{3}{|c|}{$0,03(0,85)$} \\
\hline \multirow{10}{*}{ Model 2} & Idealisme & $-(0,07$ & 0,30 & $-(0,04$ & 0,01 & 0,30 & 0,00 \\
\hline & Relativisme & 0,08 & 0,33 & 0,03 & $-0,35$ & 0,32 & $-0,15$ \\
\hline & Besaran Konsekuensi & 0,19 & 0,35 & 0,10 & 0,06 & 0,16 & 0,06 \\
\hline & Konsensus Sosial & 0,10 & 0,16 & 0,08 & 0,01 & 0,14 & 0,01 \\
\hline & Probabilitas Efek & 0,27 & 0,35 & 0,16 & $-0,06$ & 0,17 & $-0,05$ \\
\hline & Kesegeraan Temporal & 0,02 & 0,19 & 0,02 & 0,03 & 0,14 & 0,03 \\
\hline & Konsentrasi Efek & $-0,32$ & 0,21 & $-0,21$ & 0,12 & 0,16 & 0,12 \\
\hline & Kedekatan & $-0,24$ & 0,27 & $-0,12$ & $-0,12$ & 0,23 & $-0,07$ \\
\hline & $\mathbf{R}^{2}(\mathbf{F})$ & \multicolumn{3}{|c|}{$0,11(0,86)$} & \multicolumn{3}{|c|}{$0,05(0,39)$} \\
\hline & $\Delta \mathrm{R}^{2}(\Delta \mathrm{F})$ & \multicolumn{3}{|c|}{$0,09(0,90)$} & \multicolumn{3}{|c|}{$0,03(, 026)$} \\
\hline \multicolumn{8}{|c|}{ Mahasiswa Pascasarjana } \\
\hline \multirow{2}{*}{\multicolumn{2}{|c|}{ Variabel dan Skenario }} & \multicolumn{3}{|c|}{$\begin{array}{c}\text { Skenario 1 } \\
\text { (Manipulasi Laporan Keuangan) }\end{array}$} & \multicolumn{3}{|c|}{$\begin{array}{c}\text { Skenario 2 } \\
\text { (Memperpanjang Kredit yang } \\
\text { Diragukan) }\end{array}$} \\
\hline & & B & St.E & $\beta$ & B & St.E & $\boldsymbol{\beta}$ \\
\hline \multirow{7}{*}{ Model 1} & Idealisme & 0,25 & 0,22 & 0,10 & 0,532 & 0,207 & $0,235^{* *}$ \\
\hline & Relativisme & $-0,67$ & 0,16 & $-(0,37 * * *$ & $-0,462$ & 0,153 & $-0,274^{* * *}$ \\
\hline & $\mathrm{R}^{2}(\mathrm{~F})$ & \multicolumn{3}{|c|}{$0,15\left(8,90^{* * *}\right)$} & \multicolumn{3}{|c|}{$0,13\left(7,63^{* * *}\right)$} \\
\hline & Idealisme & 0,09 & 0,21 & 0,04 & 0,54 & 0,18 & $0,24^{* * *}$ \\
\hline & Relativisme & $-0,41$ & 0,16 & $-0,23^{* *}$ & $-(0,20$ & 0,13 & $-0,12$ \\
\hline & Besaran Konsekuensi & 0,25 & 0,12 & $0,22^{* *}$ & 0,38 & 0,08 & $0,40 * * *$ \\
\hline & Konsensus Sosial & 0,15 & 0,10 & 0,13 & 0,19 & 0,08 & $0,19^{* *}$ \\
\hline \multirow[t]{6}{*}{ Model 2} & Probabilitas Efek & 0,12 & 0,09 & 0,13 & 0,34 & 0,09 & $0,35^{* * *}$ \\
\hline & Kesegeraan Temporal & 0,18 & 0,09 & $0,18^{*}$ & $-0,06$ & 0,09 & $-0,07$ \\
\hline & Konsentrasi Efek & 0,08 & 0,09 & 0,10 & 0,04 & 0,08 & 0,04 \\
\hline & Kedekatan & $-0,06$ & 0,12 & $-0,05$ & $-0,06$ & 0,10 & $-0,05$ \\
\hline & $\mathbf{R}^{2}(\mathbf{F})$ & \multicolumn{3}{|c|}{$0,39\left(7,88^{* * *}\right)$} & \multicolumn{3}{|c|}{$0,51\left(12,7^{* * *}\right)$} \\
\hline & $\Delta \mathrm{R}^{2}(\Delta \mathrm{F})$ & \multicolumn{3}{|c|}{$0,24\left(6,59^{* * *}\right.$} & \multicolumn{3}{|c|}{$0,38\left(12,7^{* * *}\right)$} \\
\hline
\end{tabular}


kelompok mahasiswa sarjana baik pada skenario pertama maupun kedua. Sedangkan untuk kelompok mahasiswa pascasarjana, probabilitas efek memiliki hubungan positif signifikan di skenario kedua $(\beta=0,35 ; \quad p<0,01)$. Variabel kesegeraan temporal tidak memiliki hubungan signifikan dengan ethical intention untuk kelompok mahasiswa sarjana baik pada skenario pertama maupun kedua. Sedangkan untuk kelompok mahasiswa pascasarjana, kesegeraan temporal memiliki hubungan positif signifikan di skenario pertama $(\beta=0,18 ; \mathrm{p}<0,1)$. Terakhir, untuk variabel konsentrasi efek dan variabel kedekatan tidak memiliki hubungan signifikan baik di kelompok mahasiswa sarjana maupun pascasarjana di kedua skenario.

Dengan demikian disimpulkan, H3c tidak terdukung untuk kelompok mahasiswa sarjana dan terdukung untuk kelompok mahasiswa pascasarjana, H4c tidak terdukung untuk kelompok mahasiswa sarjana dan terdukung parsial untuk kelompok mahasiswa pascasarjana, H5c tidak terdukung untuk kelompok mahasiswa sarjana dan dan terdukung parsial untuk kelompok mahasiswa pascasarjana, H6c tidak terdukung untuk kelompok mahasiswa sarjana dan terdukung parsial untuk kelompok mahasiswa pascasarjana, terakhir H7c serta terakhir H8c tidak terdukung untuk kedua kelompok sampel.

\section{Hubungan Tingkat Pendidikan, Usia, dan Gender terhadap Ethical Recognition, Ethical Judgment, dan Ethical Intention}

Berdasarkan hasil Independent t-test yang ada di Tabel 6 di bawah ini terlihat bahwa terdapat perbedaan yang signifikan atas nilai rata-rata dari ethical judgment baik untuk skenario pertama dan skenario kedua berdasarkan tingkat pendidikan. Dengan kata lain nilai rata-rata dari ethical judgment lebih besar untuk mahasiswa pascasarjana $(\mathrm{t}=-6,29 ; \mathrm{p}<0,01$ dan $\mathrm{t}=-5,41 ; \mathrm{p}<0,01)$. Sehingga dengan demikian H9b terdukung namun tidak untuk H9a dan H9c.

Berikutnya adalah pembahasan mengenai hubungan dari gender dengan tiga tahapan proses pengambilan keputusan etis. Independent t-test dilakukan dengan lebih spesifik yakni tetap membagi sampel menjadi kedua kelompok (mahasiswa sarjana dan pascasarjana) dan kemudian dilihat pengaruh dari gender di masing-masing kelompok sampel, sehingga dengan demikian hasil yang terlihat menjadi lebih detail. Tabel 7 di bawah ini memperlihatkan bahwa nilai rata-rata ethical recognition wanita lebih besar signifikan untuk kelompok mahasiswa sarjana di skenario satu $(\mathrm{t}=1,4, \mathrm{p}<0,05)$ namun tidak ditemukan perbedaan signifikan untuk kelompok mahasiswa pascasarjana. Sehingga H10a terdukung parsial untuk kelompok mahasiswa sarjana namun tidak untuk kelompok mahasiswa pascasarjana.

Selanjutnya nilai rata-rata ethical judgment wanita lebih besar signifikan untuk kelompok mahasiswa sarjana baik di skenario pertama maupun kedua $(\mathrm{t}=-3,37, \mathrm{p}<0,01$ dan $\mathrm{t}=-1,81, \mathrm{p}<0,1)$ namun tidak ditemukan perbedaan signifikan untuk kelompok mahasiswa pascasarjana. Sehingga H10b terdukung untuk kelompok mahasiswa sarjana namun tidak untuk kelompok mahasiswa pascasarjana. Terakhir H10c tidak terdukung untuk kedua kelompok sampel, namun secara mengejutkan ditemukan hubungan signifikan yang berlawanan dengan prediksi. Bahwa ternyata di kelompok mahasiswa pascasarjana untuk tahapan ethical intention justru mahasiswa pria lebih etis dibandingkan wanita $(\mathrm{t}=2,00 ; \mathrm{p}<0,05)$.

Analisis terakhir terkait pengaruh dari variabel individual, adalah mengenai usia. Pada bagian demografi telah dijelaskan bahwa ternyata usia dari kedua kelompok sampel (mahasiswa sarjana dan pascasarjana) hampir tidak terlalu berbeda, dimana sebagian besar sampel yakni sebesar $82 \%$ memiliki usia di rentang 20-25 tahun, oleh karenanya uji beda atas kelompok berdasarkan usia di bawah ini akan dijadikan satu untuk mahasiswa sarjana dan pascasarjana. Dapat dilihat pada Tabel 8, tidak ditemukan perbedaan di keseluruhan tahapan proses pengambilan keputusan etis berdasarkan usia. Sehingga dengan demikian H11a, H11b, dan H11c tidak terdukung.

\section{Diskusi}

Hasil regresi maupun uji beda yang telah disimpulkan pada Tabel 9 berikut ini memperlihatkan bahwa idealisme merupakan variabel yang memiliki hubungan positif signifikan paling kuat dengan ketiga tahapan proses pengambilan keputusan etis. Alasan di balik temuan tersebut adalah jika dilihat dari Tabel 4.2 diketahui bahwa rata-rata variabel idealisme $(3,98)$ lebih tinggi dibandingkan rata-rata variabel relativisme $(3,45)$. Hal tersebut menunjukkan bahwa mahasiswa akuntansi (sarjana dan pascasarjana) yang menjadi responden pada penelitian ini cenderung untuk memberikan bobot yang lebih tinggi pada filsafat moral yang idealistik dibandingkan filsafat moral yang relativistik ketika membuat keputusan etis. 
Dengan kata lain mahasiswa yang menjadi responden dalam penelitian ini dapat dicap sebagai "absolutis" (idealisme tinggi dan relativisme rendah) atau mereka yang percaya bahwa tindakan mereka harus menghormati aturan moral universal dan harus menghasilkan konsekuensi positif bagi semua pihak yang terlibat (Forsyth, 1992).
Relativisme juga ditemukan memiliki hubungan negatif signifikan dengan berbagai tingkat hubungan yang berbeda-beda di lintas keseluruhan tahapan pengambilan keputusan etis. Sparks dan Hunt (1998) menjelaskan dua alasan yang dapat menjelaskan hubungan negatif antara relativisme dengan tahap pengambilan keputusan etis. Pertama, ketidakpercayaan atau penolakan pada

Tabel 6. Perbedaan Ethical Recognition, Ethical Judgment, dan Ethical Intention berdasarkan Tingkat Pendidikan

\begin{tabular}{|c|c|c|c|}
\hline $\begin{array}{l}\text { Tahapan Proses Pengambilan } \\
\text { Keputusan Etis dan Skenario }\end{array}$ & $\begin{array}{c}\text { Mahasiswa Sarjana } \\
\text { M (SD) } \\
\mathbf{N}=65 \\
\end{array}$ & $\begin{array}{c}\text { Mahasiswa Pascasarjana } \\
\text { M (SD) } \\
\mathrm{N}=108 \\
\end{array}$ & $t$ \\
\hline \multicolumn{4}{|l|}{ Ethical Recognition } \\
\hline Skenario 1 & $4,18(0,49)$ & $4,11(0,64)$ & 0,78 \\
\hline Skenario 2 & $3,91(0,57)$ & $3,94(0,80)$ & $-0,32$ \\
\hline \multicolumn{4}{|l|}{ Ethical Judgment } \\
\hline Skenario 1 & $3,35(0,77)$ & $4,07(0,63)$ & $-6,29^{* * *}$ \\
\hline Skenario 2 & $3,07(0,83)$ & $3,75(0,78)$ & $-5,41^{* * *}$ \\
\hline \multicolumn{4}{|l|}{ Ethical Intention } \\
\hline Skenario 1 & $3,60(0,88)$ & $3,49(1,04)$ & 0,70 \\
\hline Skenario 2 & $3,38(0,84)$ & $3,32(0,96)$ & 0,42 \\
\hline
\end{tabular}

Tabel 7. Perbedaan Ethical Recognition, EthicalJudgment, dan Ethical Intention berdasarkan Gender

\begin{tabular}{|c|c|c|c|c|c|c|}
\hline \multirow{4}{*}{$\begin{array}{c}\text { Tahapan Proses } \\
\text { Pengambilan } \\
\text { Keputusan Etis } \\
\text { dan Skenario }\end{array}$} & \multicolumn{3}{|c|}{ Mahasiswa Sarjana } & \multicolumn{3}{|c|}{ Mahasiswa Pascasarjana } \\
\hline & Pria & Wanita & & Pria & Wanita & \\
\hline & $\mathrm{M}$ (SD) & M (SD) & $t$ & M (SD) & $\mathrm{M}(\mathrm{SD})$ & $t$ \\
\hline & $\mathrm{N}=20$ & $\mathrm{~N}=45$ & & $\mathrm{~N}=32$ & $\mathrm{~N}=76$ & \\
\hline \multicolumn{7}{|l|}{ Ethical Recognition } \\
\hline Skenario 1 & $4,00(0,45)$ & $4,26(0,49)$ & $-1,4^{* *}$ & $4,15(0,72)$ & $4,09(0,61)$ & 0,46 \\
\hline Skenario 2 & $3,90(0,44)$ & $3,91(0,63)$ & $-0,07$ & $3,81(0,96)$ & $4,00(0,73)$ & $-0,98$ \\
\hline \multicolumn{7}{|l|}{ Ethical Judgment } \\
\hline Skenario 1 & $2,90(0,71)$ & $3,55(0,72)$ & $-3,37^{* * *}$ & $4,09(0,64)$ & $4,06(0,63)$ & 0,20 \\
\hline Skenario 2 & $2,80(0,69)$ & $3,20(0,86)$ & $-1,81^{*}$ & $3,65(0,86)$ & $3,80(0,74)$ & $-0,88$ \\
\hline \multicolumn{7}{|l|}{ Ethical Intention } \\
\hline Skenario 1 & $3,55(0,88)$ & $3,62(0,88)$ & $-0,30$ & $3,78(1,03)$ & $3,34(1,03)$ & $2,00^{* *}$ \\
\hline Skenario 2 & $3,20(0,69)$ & $3,46(0,89)$ & $-1,18$ & $3,53(1,04)$ & $3,21(0,92)$ & 1,57 \\
\hline
\end{tabular}

Tabel 8. Perbedaan Ethical Recognition, EthicalJudgment, dan Ethical Intention berdasarkan Usia

\begin{tabular}{|c|c|c|c|c|c|}
\hline \multirow[b]{2}{*}{$\begin{array}{l}\text { Tahapan Proses Pengambilan } \\
\text { Keputusan Etis dan Skenario }\end{array}$} & \multicolumn{5}{|c|}{ Mahasiswa Sarjana dan Mahasiswa Pascasarjana } \\
\hline & $\begin{array}{c}20-25 \text { tahun } \\
\mathrm{M} \text { (SD) } \\
\mathrm{N}=142\end{array}$ & $\begin{array}{c}25-30 \text { tahun } \\
\text { M (SD) } \\
\mathbf{N}=20\end{array}$ & $\begin{array}{c}30-35 \text { tahun } \\
\text { M (SD) } \\
\text { N= } 7\end{array}$ & $\begin{array}{c}>35 \text { tahun } \\
\mathrm{M} \text { (SD) } \\
\mathrm{N}=4\end{array}$ & $\mathbf{F}$ \\
\hline Ethical Recognition & & & & & \\
\hline Skenario 1 & $4,14(0,57)$ & $4,10(0,64)$ & $4,00(1,00)$ & $4,25(0,50)$ & 0,21 \\
\hline Skenario 2 & $3,92(0,71)$ & $3,90(0,91)$ & $4,00(0,81)$ & $4,00(0,00)$ & 0,04 \\
\hline Ethical Judgment & & & & & \\
\hline Skenario 1 & $3,75(0,79)$ & $4,00(0,64)$ & $4,28(0,75)$ & $3,75(0,50)$ & 1,55 \\
\hline Skenario 2 & $3,45(0,87)$ & $3,60(0,94)$ & $3,85(0,69)$ & $4,00(0,00)$ & 1,04 \\
\hline Ethical Intention & & & & & \\
\hline Skenario 1 & $3,53(0,97)$ & $3,60(0,99)$ & $3,57(1,27)$ & $3,00(1,15)$ & 0,42 \\
\hline Skenario 2 & 3,31 $(0,91)$ & $3,45(1,05)$ & $3,57(0,78)$ & $3,50(0,57)$ & 0,31 \\
\hline
\end{tabular}


Tabel 9. Simpulan Temuan Hubungan antara Faktor Internal dan Eksternal terhadap Tiga Tahapan Proses Pengambilan Keputusan Etis untuk Kedua Kelompok Mahasiswa Sarjana dan Pascasarjana

\begin{tabular}{|c|c|c|c|}
\hline \multirow[t]{2}{*}{ Faktor } & \multicolumn{3}{|c|}{ Tahapan Proses Pengambilan Keputusan Etis } \\
\hline & Ethical Recognition & EthicalJudgment & Ethical Intention \\
\hline \multicolumn{4}{|l|}{ Faktor Internal } \\
\hline $\begin{array}{l}\text { Filosofi Moral Personal } \\
\text { 1. Variabel Idealisme }\end{array}$ & $\begin{array}{c}+ \text { sign } \\
(\mathrm{p}<0,05 ;<0,01)\end{array}$ & $\begin{array}{c}+ \text { sign } \\
(p<0,05)\end{array}$ & $\begin{array}{c}+ \text { sign } \\
(p<0,05)\end{array}$ \\
\hline 2. Variabel relativisme & $\begin{array}{c}- \text { sign } \\
p<0,05)\end{array}$ & $\begin{array}{l}- \text { sign } \\
(-<0,1)\end{array}$ & $\begin{array}{l}- \text { sign } \\
(p<0,05)\end{array}$ \\
\hline 3. Tingkat Pendidikan & $\mathbf{X}$ & $\begin{array}{c}+ \text { sign } \\
(p<0,01)\end{array}$ & $\mathbf{x}$ \\
\hline 4. Gender $($ Female +$)$ & $\begin{array}{c}\text { Female + sign } \\
\quad(p<0,05)\end{array}$ & $\begin{array}{l}\text { Female+ sign } \\
(p<0,1 ;<0,05)\end{array}$ & $\begin{array}{l}\text { Male- sign } \\
(\mathrm{p}<0,05)\end{array}$ \\
\hline 5. Usia & $\mathrm{X}$ & $\mathbf{x}$ & $\mathbf{x}$ \\
\hline \multicolumn{4}{|l|}{$\begin{array}{l}\text { Faktor Eksternal } \\
\text { Dimensi Intensitas Moral }\end{array}$} \\
\hline 1. Besaran Konsekuensi & $\mathbf{X}$ & $\begin{array}{c}+ \text { sign } \\
(\mathrm{p}<0,1)\end{array}$ & $\begin{array}{c}+ \text { sign } \\
(\mathrm{p}<0,05 ;<0,01)\end{array}$ \\
\hline 2. Konsensus Sosial & $\begin{array}{c}+ \text { sign } \\
(p<0,1 ;<0,05 ;<0,01)\end{array}$ & $\begin{array}{c}+ \text { sign } \\
(p<0,1 ;<0,01)\end{array}$ & $\begin{array}{l}+ \text { sign } \\
(\mathrm{p}<0,05)\end{array}$ \\
\hline 3. Probabilitas Efek & $\begin{array}{c}- \text { sign } \\
(\mathrm{p}<0,1 ;<0,05)\end{array}$ & $\mathbf{x}$ & $\begin{array}{c}+ \text { sign } \\
(p<0,01)\end{array}$ \\
\hline 4. Kesegeraan Temporal & $\begin{array}{l}+ \text { sign } \\
(\mathrm{p}<0,1)\end{array}$ & $\mathbf{x}$ & $\begin{array}{l}+ \text { sign } \\
(\mathrm{p}<0,1)\end{array}$ \\
\hline 5. Konsentrasi Efek & $\begin{array}{l}+ \text { sign } \\
(\mathrm{p}<0,05)\end{array}$ & $\mathbf{x}$ & $\mathbf{x}$ \\
\hline 6. Kedekatan & $\begin{array}{l}- \text { sign } \\
(\mathrm{p}<0,05)\end{array}$ & $\begin{array}{l}+ \text { sign } \\
(\mathrm{p}<0,1)\end{array}$ & $\mathbf{x}$ \\
\hline
\end{tabular}

kemutlakan moral mungkin dapat mengurangi kemungkinan pelanggaran etika. Dalam dunia dimana semua masalah adalah relatif dan cenderung bernuansa abu-abu, masalah etika mungkin dapat berbaur dengan segala sesuatu yang lain. Kedua, individu yang cenderung bersikap relativisme mungkin mempertimbangkan masalah etika secara umum menjadi kurang penting dibandingkan individu yang bersikap idealisme.

Hasil terkait filosofi moral personal tersebut sejalan dengan temuan penelitian yang juga dilakukan di negara-negara yang memiliki karakteristik hampir sama dengan Indonesia, yakni mayoritas Muslim, bahwa orang Muslim memang lebih bersifat idealistik dibandingkan relativistik (contoh: di Negara Egypt dan Arab Saudi oleh Marta et al., 2003; Moroko oleh Oumlil dan Balloun, 2008). Sehingga hasil tersebut juga menyiratkan bahwa salah satu pendekatan yang dapat dipertimbangkan untuk meningkatkan etika dalam proses pengambilan keputusan dalam lingkungan bisnis, khususnya di Indonesia, adalah dengan mendorong filosofi yang idealis dan mencegah filosofi yang relatif. Terkait dimensi intensitas moral, keenam variabel memiliki temuan signifikan dengan level yang berbeda di ketiga tahapan proses pengambilan keputusan etis. Variabel yang memiliki frekuensi hubungan signifikan paling banyak hingga paling sedikit secara berturut-turut adalah: konsensus sosial, besaran konsekuensi dan kesegeraan temporal. Sedangkan untuk konsentrasi efek, kedekatan, dan probabilitas efek memiliki frekuensi temuan signifikan yang sama dan paling sedikit. Hasil temuan ini sejalan dengan temuan milik Barnett dan Valentine (2004) dan Cohen dan Bennie (2006) bahwa untuk komponen besaran konsekuensi, frekuensi ditemukannya hubungan positif signifikan dengan ketiga tahapan proses pengambilan keputusan etis lebih banyak dibandingkan kesegeraan temporal. Alasan yang dapat menjelaskan temuan ini adalah ketika individu dihadapkan dengan komponen besaran konsekuensi (magnitude of consequence) dan kesegeraan temporal (temporal immediacy) secara bersamaan, maka individu tersebut akan mempertimbangkan kecepatan konsekuensi pada komponen besaran konsekuensi daripada kesegeraan temporal. Kondisi yang berbeda akan diperoleh bila individu tersebut diberikan komponen besaran 
konsekuensi dan kesegeraan temporal secara terpisah (Barnett dan Valentine, 2004).

Hasil tersebut juga selaras dengan pendapat yang dikemukakan oleh Morris dan McDonald (1995) yang menyatakan bahwa besaran konsekuensi dan konsensus sosial merupakan pengukur utama diantara enam komponen lainnya dalam memprediksi intensitas moral sedangkan untuk konsentrasi efek merupakan komponen yang tidak pernah berkontribusi dalam memprediksi intensitas moral, serta Musbah (2010) yang hanya menguji pengaruh dari besaran konsekuensi, konsensus sosial, serta kesegeraan temporal.

Masih terkait variabel-variabel dari dimensi intensitas moral, sebagai tambahan, menariknya probabilitas efek ditemukan memiliki hubungan negatif signifikan terhadap ethical recognition. Sehingga dengan kata lain, semakin besar kemungkinan kerugian aktual yang terjadi dari suatu tindakan, maka semakin rendahnya kesadaran responden bahwa situasi tersebut melibatkan permasalahan etika. Hal yang mungkin bisa menjadi penjelasan dari hasil ini adalah sesuatu yang masih belum terjadi (ditonjolkan dengan kata "kemungkinan”) tidak dianggap sebagai prasyarat utama dalam mengakui bahwa suatu tindakan melibatkan problema etika. Lain halnya jika sesuatu tersebut "akan" terjadi.

Selain itu, untuk variabel kedekatan juga ditemukan memiliki hubungan negatif signifikan terhadap tahapan ethical recognition. Dengan kata lain, semakin suatu tindakan memengaruhi rekan kerjanya, maka semakin rendahnya kesadaran responden bahwa situasi tersebut melibatkan problema etika. Alasan yang mungkin bisa menjadi penyebabnya adalah karena, pengaruh yang ditimbulkan dari tindakan tidak etis terhadap rekan kerja bisa jadi bersifat positif bukannya negatif, karena aktor yang diceritakan di skenario juga memiliki kedudukan yang sama dengan rekanrekan kerjanya.

Terkait pengaruh dari variabel individu berupa tingkat pendidikan, gender, dan usia juga menunjukkan hasil yang beberapa di antaranya selaras dengan hasil temuan sebelumnya namun juga kontradiktif. berdasarkan hasil independent t-test dan anova one-way yang dijelaskan pada bagian sebelumnya terlihat bahwa tingkat pendidikan hanya berpengaruh hanya pada tahapan ethical judgment dalam proses pengambilan keputusan etis. Ethical judgment merupakan merupakan proses kognitif dimana individu menentukan tindakan manakah yang benar atau salah. Menentukan antara tindakan yang benar dan salah merupakan elemen vital dalam tahapan ini. Tahapan ini sangat ditentukan oleh cognitive moral development (CMD) seseorang. Kohlberg (1969, 1976) menyatakan bahwa proses kognitif dari pengambilan keputusan etis menjadi semakin rumit ketika individu mulai berkembang, dan salah satu faktor kuat yang mempengaruhi hal tersebut adalah tingkat pendidikan itu sendiri.

Selanjutnya, tidak ditemukannya hubungan tingkat pendidikan dengan ethical recognition dan ethical intention sejalan dengan temuan milik Nill dan Schibrowsky (2005); Shafer et al. (2001) Meskipun banyak penelitian yang mengungkapkan bahwa tingkat pendidikan memainkan peran yang penting dalam proses pengambilan keputusan etis, namun riset-riset menyajikan hasil yang tidak konsisten. Musbah(2010) menyatakan bahwa sampel yang menggunakan mahasiswa dapat menjadi alasan atas tidak adanya hubungan yang signifikan antara tingkat pendidikan dengan proses pengambilan keputusan etis. Terdapat indikasi bahwa pendidikan etika yang telah diberikan di perkuliahan -yang mana relatif singkat- belum mampu meningkatkan sensitivitas mahasiswa dalam mengidentifikasi situasi-situasi dilema etis (Sofyani et al., 2016).

Wright (1995) menyatakan bahwa pendidikan memang merupakan cara terbaik untuk mengembangkan perilaku etis dalam lingkungan bisnis modern dewasa ini, namun tetap perlu disadari bahwa proses penginternalisasian nilai-nilai etika dalam diri seseorang membutuhkan waktu yang lama serta dukungan dari faktor-faktor lain seperti keluarga dan lingkungan eksternal. Alasan kedua adalah, mahasiswa bisnis memiliki kecenderungan untuk mengabaikan pertimbangan etis demi mendapatkan keuntungan ekonomi, sehingga tingkat pendidikan pada mahasiswa bisnis mungkin tidak menjadi faktor penentu bagi mahasiswa tersebut untuk bersikap etis (Schibrowsky et al., 1995).

Alasan terakhir yang dapat menjelaskan temuan ini adalah, jika dilihat dari Tabel 1 mengenai demografi responden, diketahui bahwa meskipun terdapat pembeda yang cukup jelas antara grup berdasarkan tingkat pendidikan yakni 108 responden berpendidikan pascasarjanadan 65 responden berpendidikan sarjana, namun mayoritas usia dari responden dalam penelitian ini adalah sama. Artinya bahwa, tanpa melihat tingkat pendidikan yang ditempuh, mayoritas responden berusia 20-25 tahun. Terdapat kemungkinan bahwa mahasiswa yang menjadi responden dalam penelitian ini ketika baru lulus di tingkat sarjana langsung 
melanjutkan pendidikannya ke jenjang selanjutnya tanpa pernah mengecap dunia kerja sebelumnya. Oleh karenanya, tingkat pengalaman terutama dalam dunia kerja mungkin dapat lebih menjelaskan dibandingkan tingkat pendidikan ketika dikaitkan hubungannya dengan intensi etis. Dengan menggunakan sampel mahasiswa sebagai proksi praktisi untuk menyelesaikan kuesioner termasuk skenario bisnis, bisa jadi mereka menghadapi kesulitan untuk mampu merespon secara memadai. Hal tersebut dikarenakan mereka masih memiliki pengetahuan praktis yang sedikit tentang situasi bisnis tertentu (Weber, 1992).

Variabel gender, berdasarkan hasil yang dipaparkan di atas, sesuai dengan yang telah banyak ditemukan di penelitian sebelumnya bahwa wanita memang cenderung lebih bersikap etis dibandingkan pria. Hal tersebut terlihat dari adanya hubungan signifikan di tahapan ethical recognition dan ethical judgment namun hanya pada kelompok mahasiswa sarjana. Selain itu temuan mengejutkan adalah pada tahapan ethical intention, ternyata pria lebih menunjukkan perilaku yang pro etis dibandingkan wanita, dan hal tersebut ditemukan hanya pada kelompok mahasiswa pascasarjana.

Hal yang mungkin dapat menjadi penjelasan adalah mahasiswa pascasarjana yang diambil disini beberapa di antaranya adalah mahasiswa Magister Akuntansi yang tampaknya telah memiliki pengalaman kerja, sehingga dengan dimilikinya pengalaman di dunia kerja sesungguhnya, mereka mungkin sedikit terpengaruh dengan isu-isu etis yang dihadapi di tempat kerja mereka sehari-hari, seperti misalnya memanipulasi laporan keuangan adalah hal yang secara lumrah terjadi. Kemudian, terkait kontradiktifnya hasil dari tahapan ethical intention dapat dijelaskan oleh pendapat dari Chan dan Leung (2006) bahwa individu yang menunjukkan kesuksesan dalam satu tahapan sebelumnya mungkin tidak cukup sukses di tahapan selanjutnya sehingga terjadi ethical failure. Kejadian tersebut dapat terjadi misal karena individu yang terlah mengidentifikasi adanya problem etis dalam suatu situasi mungkin tidak memiliki penalaran moral yang cukup atau lengkap untuk menentukan tindakan moral di tahapan selanjutnya.

\section{SIMPULAN}

Literatur pengambilan keputusan etis dalam dunia bisnis (O'Fallon dan Butterfield, 2005; Ferrell dan Fraedrich, 1997; Rest et al., 1986;
Chang dan Leung, 2006) telah membagi beberapa faktor yang dapat mempengaruhi proses pengambilan keputusan etis. Penelitian ini menggunakan dua jenis faktor, yakni faktor internal (berdasarkan karakteristik individu: filosofi moral personal yang terdiri dari idealisme dan relativisme, tingkat pendidikan, gender dan usia) serta faktor eksternal (intensitas moral yang memiliki enam variabel yaki besaran konsekuensi, konsensus sosial, probabilitas efek, kesegeraan temporal, konsentrasi efek, dan kedekatan).

Penelitian ini menemukan bukti empiris bahwa dari keseluruhan variabel yang dihipotesiskan, beberapa di antaranya ditemukan hubungan signifikan terhadap tiga tahapan proses pengambilan keputusan etis (ethical recognition, judgment, dan intention) dengan level yang berbedabeda (tingkat signifikansi yang berbeda, di skenario yang berbeda). Seluruh variabel yang dihipotesiskan ditemukan memiliki hubungan signifikan dengan ketiga tahapan pengambilan keputusan etis tersebut baik di salah satu skenario pertama maupun kedua, kecuali untuk variabel usia.

Selaras dengan temuan penelitian-penelitian sebelumnya, idealisme pada penelitian ini memiliki hubungan positif signifikan dan relativisme memiliki hubungan negatif signifikan dengan tahapan pengambilan keputusan etis. Terkait dimensi intensitas moral, umumnya keenam variabel memiliki hubungan positif signifikan dengan level yang berbeda-beda di ketiga tahapan proses pengambilan keputusan etis, kecuali probabilitas efek dan kedekatan yang ditemukan memiliki hubungan negatif signifikan dengan ethical recognition. Hasil yang ditemukan adalah sesuai dengan pendapat yang dikemukakan oleh Morris dan McDonald (1995), bahwa besaran konsekuensi dan konsensus sosial merupakan pengukur utama di antara enam komponen lainnya dalam memprediksi intensitas moral.

Selanjutnya, terkait variabel individu berupa tingkat pendidikan, gender, dan usia, keseluruhannya memiliki hubungan positif signifikan kecuali untuk usia yang tidak memiliki hubungan signifikan. Lebih rincinya, tingkat pendidikan hanya memiliki hubungan positif dengan ethical judgment. Hal menarik lainnya adalah untuk kelompok mahasiswa pascasarjana, ternyata ketika mencapai tahapan ethical intention, pria justru lebih memiliki peluang untuk bertindak dalam suatu tindakan etis dibandingkan wanita.

Implikasi teoretis dari penelitian ini diharapkan dapat menambah bukti empiris dari literatur mengenai pengambilan keputusan etis di 
lingkup bisnis terutama dengan menggunakan dua jenis kelompok mahasiswa akuntansi yang berbeda jenjang pendidikan, yakni mahasiswa sarjana dan pascasarjana, secara khususnya mengenai faktorfaktor yang mempengaruhi tiga tahapan proses pengambilan keputusan etis.

Implikasi praktis dari penelitian ini diharapkan dapat memberian bahan masukan bagi pihak akademisi dalam menyusun kurikulum pembelajaran untuk mahasiswanya agar kemampuan mahasiswa dalam mengindentifikasi isu-isu etis menjadi meningkat. Hal ini selaras dengan temuan Haron et al. (2015). Hasil penelitian Haron et al. (2015) menemukan bahwa eksposur etika memengaruhi tingkat ethical judgment, sehingga hal tersebut memberikan implikasi bahwa pemerintah perlu meningkatkan dan melakukan penilaian kembali atas sistem pendidikan dengan menempatkan penekanan yang lebih pada pendidikan etika. Implikasi praktis lainnya, terkait hasil temuan mengenai filosofi moral personal menyiratkan bahwa salah satu pendekatan yang dapat dipertimbangkan untuk meningkatkan etika dalam proses pengambilan keputusan dalam lingkungan bisnis, khususnya di Indonesia, adalah dengan mendorong filosofi yang idealis dan mencegah filosofi yang relatif.

Penelitian ini tidak luput dari beberapa keterbatasan. Seperti yang terlihat di tabel demografi, terdapat komposisi yang tidak seimbang terkait gender, dimana separuh lebih dari responden penelitian ini adalah wanita. Penelitian selanjutnya diharapkan memperhatikan hal tersebut. Selain itu penelitian ini juga hanya terbatas pada sampel berupa mahasiswa sarjana dan pascasarjana akuntansi sehingga diperlukan kehati-hatian untuk menggeneralisasi hasil penelitian ke populasi lain. Penelitian selanjutnya dapat memperluas cakupan jenis responden, misal dengan meneliti kelompok mahasiswa bisnis lainnya seperti manajemen dan ekonomi, serta juga terkait tingkat pendidikan dapat diperluas mulai dari mahasiswa diplopma hingga mahasiswa doktor. Untuk lebih menambah kekomprehensifan hasil penelitian, kelompok responden dapat juga diperluas ke praktisi yang berkaitan dengan bisnis secara umumnya dan akuntansi secara khususnya seperti auditor eksternal, auditor internal, akuntan manajemen, konsultan pajak, hingga ke kalangan pendidik.

Kelemahan lain adalah faktor eksternal yang dipertimbangkan dalam penelitian ini belum mencakup variabel yang berkaitan dengan organisasi dengan catatan bahwa responden adalah mereka yang telah bekerja.Dari sisi metodologis, penelitian selanjutnya dapat menggunakan desain metodologi yang berbeda seperti dengan menggunakan eksperimen. Skenario mengenai isu akuntansi dapat dimanipulasi, sehingga dengan demikian kausalitas antar variabel yang diteliti menjadi lebih baik karena dikontrolnya pengaruh dari variabelvariabel lain.

\section{DAFTAR PUSTAKA}

Abdolemohammadi, M. J., dan C. R. Baker. 2006. Accountants' Value Preferences and Moral Reasoning. Journal of Business Ethics, 69, 11-25.

Ajzen, I. 1991. The Theory of Planned Behavior. Organizational Behavior and Human Decision Processes, 50 (2), 179-211.

Arestanti, M. A., Herawati, N., dan Rahmawati, E. 2016. Faktor-Faktor Internal Individual dalam Pembuatan Keputusan Etis: Studi pada Konsultan Pajak di Kota Surabaya. Jurnal Akuntansi dan Investasi, 17 (2), 104117.

Barnett, T., dan S. Valentine. 2004. Issue Contingencies and Marketers' Recognition of Ethical Issues, Ethical Judgments and Behavioral Intentions. Journal of Business Research, 57 (4), 338-346.

Bernard, P., dan B. Sweeney. 2010. The Relationship Between Demographic Variables and Ethical Decision Making of Trainee Accountants. International Journal of Auditing, 14 (1), 79-99.

Betz, M., L. O'Connell dan J. M. Shepard. 1989. Gender Differences in Proclivity for Unethical Behavior. Journal of Business Ethics, 8 (5), 321-324.

Browning, J., dan N. B. Zabriskie. 1983. How Ethical are Industrial Buyers. Industrial Marketing Management, 12 (4), 219-224.

Cagle, J., dan M. Baucus. 2006. Case Studies of Ethics Scandals: Effects on Ethical Perceptions of Finance Students. Journal of Business Ethics, 64 (3), 213-229.

Carlson, D. S., K. M. Kacmar dan L. L. Wadsworth. 2002. The Impact of Moral Intensity Dimensions on Ethical Mecision making: Assessing The Relevance of Orientation. Journal of Managerial Issues, $14(1), 15$.

Chan, S. Y. S., P. dan Leung. 2006. The Effects of Accounting Students' Ethical Reasoning and Personal Factors on Their Ethical 
Sensitivity. Managerial Auditing Journal, 21 (4), 436-457.

Cohen, J. R., N. M. dan Bennie. 2006. The Applicability of a Contingent Factors Model to Accounting Ethics Research. Journal of Business Ethics, 68 (1), 1-18.

Davis, M. A., Andersen, M. G., dan Curtis, M. B. 2001. Measuring Ethical Ideology in Business Ethics: A Critical Analysis of The Ethics Position Questionnaire. Journal ofBusiness Ethics, 32, 35-53.

Dubinsky, A. J., R. Nataraajan dan H. Wen-Yeh. 2004. The Influence of Moral Philosophy on Retail Salespeople's Ethical Perceptions. Journal of Consumer Affairs, 38 (2), 297319.

Ferrell, O. C., dan J. Fraedrich. 1997. Business Ethics: Ethical Decision Making and Cases. Boston Mass: Houghton Mifflin.

Fritzsche, D. J., dan E. Oz. 2007. Personal Values' Influence on The Ethical Dimension of Decision Making. Journal of Business Ethics, 75, 335-343.

Forsyth, D. R. 1980. Taxonomy of Ethical Ideologies. Journal of Personality and SocialPsychology, 39 (1), 175-184.

Forsyth, D. R. 1992. Judging the Morality of Business Practices: The Influence of Personal Moral Philosophies. Journal of Business Ethics, 11 (5), 461-470.

Gowing, M. P., K. Norm., G. P. W. Lan, M. Sharon, dan R. Fritz. 2005. Differences By Gender in The Moral Reasoning, Personal and Value Types of Accounting Majors: a Study.Journal of Academy of Business and Economics.

Ghozali, I. 2009. Aplikasi Analisis Multivariate dengan Program SPSS. Semarang: Badan Penerbit UNDIP.

Guffey, D. M., dan M. W. McCartney. 2007. The Perceived Importance of an Ethical Iissue As a Determinant of Ethical DecisionMaking for Accounting Students in an Academic Setting. Accounting Education, 17 (3), 1-22.

Haron, H., I. Ismail, dan A. Na. 2015. The Effect of Moral Reasoning, Exposure to Ethics and Perceived Ethical Climate on Ethical Judgement of Auditors in Malaysia. Asian Journal of Business and Accounting, 8 (2), 25-65.

Jones, T. M. 1991. Ethical Decision Making by Individual in Organization: An Issue-
Contigent Model. Academy of Management Review, 16 (2), 366-395.

Kohlberg, L. 1969. Stages in The Development of Moral Thought and Action. New York: Holt, Rinehart and Winston.

Kohlberg, L. 1976. Moral Stages And Moralization: The Cognitive Development Approach. Moral Development and Behavior: Theory Of Research and Social Issue.

Langley, A., H. Mintzberg, P. Pitcher, E. Posada, dan J. Saint-Macary. 1995. Opening up Decision Making: The View from The Black Stool. Organization Science , 6 (3), 260-279.

Leitsch, D. L. 2004. Differences in The Perceptions of Moral Intensity in The Moral Decision Process: An Empirical Examination of Accounting Students. Journal of Business Ethics, 53 (3), 313-323.

Marta, J. K. M., A. Attia, A. Singhapakdi, dan N. Atteya. 2003. A Comparison of Ethical Perceptions and Moral Philosophies of American and Egyptian Business Students. Teaching Business Ethics, 7 (1), 1-20.

McPhail, K., dan D. Walters. 2009. Accounting and Business Ethics: An Introduction. New York: Routledge.

Morris, S.A. dan R.A. McDonald. 1995. The Role of Moral Intensity in Moral Judgment: An Empirical Investigation. Journal Of Business Ethics, 14, 715-726.

Musbah, A. Y.S. 2010. The Role of Individual Variables, Organizational Variables, and Moral Intensity Dimensions in Accountants' Ethical Decision Making: A Study of Management Accounting in Libya. The University of Huddersfield.

Nahartyo, E., dan I. Utami. 2015. Panduan Praktis Riset Eksperimen. Jakarta: Indeks.

Nill, A., dan J. A. Schibrowsky. 2005. The Impact of Corporate Culture, The Reward System, and Perceived Moral Intensity on Marketing Students' Ethical Decision Making. Journal of Marketing Education, 27 (1), 68-80.

Nguyen, N. T., dan M. Biderman. 2008. Studying Ethical Judgments and Behavioral Intentions Using Structural Equations: Evidence from the Multidimensional Ethics Scale. Journal of Business Ethics, 83 (4), 627-640.

O'Fallon, M. J., dan K. D. Butterfield. 2005. A Review of The Empirical Ethical DecisionMaking Literature: 1996-2003. Journal of Business Ethics, 59, 375-413. 
Oumlil, A., dan J. Balloun. 2008. Ethical DecisionMaking Differences Between American and Moroccan Managers. Journal of Business Ethics.

Pangesti, M. Y. 2014. Persepsi Intensitas Moral dalam Proses Pembuatan Keputusan Moral. Jurnal Ilmu \& Riset Akuntansi, 3 (10), 1-19.

Rest, J. R. (1976). New approaches in the assessment of moral judgment. Moral development and behavior: Theory, research, and social issues, 198-218.

Rest., J., S. J. Thoma, Y. L. Moon, dan I. Getz. 1986. Different Cultures: Sexes and Religions.Moral Development: Advances in Research and Theory, 82-132.

Schibrowsky, A. John dan J. W. Peltier. 1995.The Dark Side of Experiential Learning.The Journal of Marketing Education, 17 (1),1324.

Schlenker, B. R dan D. R. Forsyth. 1977. On The Ethic On Phychological Research. Journal of Experimental Social Phychology, 13, 36996.

Shafer, W. E., R. E. Morris dan A. A. Ketchand. 1999. Effects of Personal Values on Auditors' Ethical Decisions. Accounting,
Auditing \&Accountability Journal, 14 (3), 254-277.

Sofyani, H., M. R. F. Anggraini dan S. Ayunani. 2016. Islamic Education Mentoring Program and the Religiousity of Prospective Accountant. Shirkah: Journal of Economics and Business, 1 (2).

Sparks, J. R., dan S. D. Hunt. 1998. Marketing Researcher Ethical Sensitivity: Conceptualization, Measurement, and Exploratory Investigation. Journal of Marketing, 62 (2), 92-109.

Sweeney, B., dan F. Costello. 2009. Moral Intensity and Ethical Decision-making: An Empirical Examination of Undergraduate Accounting and Business Students. Accounting Education, 18 (1), 75-97.

Weber, J. J. W. 1992. Scenarios in Business Ethics Research: Review, Critical Assessment, and Recommendations. Business Ethics Quarterly, 2 (2), 137-160.

Wright, M. 1995. Can Moral Judgement and Ethical Behaviour Be Learned? A Review of The Literature.Management Decision, 33 (10), 17.

\section{LAMPIRAN}

\section{Sangat Tidak Setuju}

1
Tidak Setuju

2
Ragu-ragu

3

\section{Setuju \\ 4}

Sangat Setuju 5

1. Seseorang harus memastikan bahwa tindakannya tidak pernah dimaksudkan $\begin{array}{lllllll}1 & 2 & 3 & 4 & 5\end{array}$ untuk menyakiti orang lain, sekecil apapun.

2. Sekecil apapun risiko yang akan ditanggung, tindakan menyakiti orang lain $\quad \begin{array}{lllllll}1 & 2 & 3 & 4 & 5\end{array}$ tidak dapat ditolerir.

3. Berapapun keuntungan yang didapat, menyakiti orang lain adalah tindakan $\quad \begin{array}{llllll}1 & 2 & 3 & 4 & 5\end{array}$ salah.

4. $\quad$ Seseorang seharusnya jangan pernah menyakiti orang lain baik secara fisik $\quad \begin{array}{lllllllll}1 & 2 & 3 & 4 & 5\end{array}$ maupun secara psikologis.

5. Seseorang tidak boleh melakukan tindakan yang bisa mengancam martabat $\quad \begin{array}{lllllll}1 & 2 & 3 & 4 & 5\end{array}$ dan kesejahteraan orang lain.

6. Jika suatu tindakan dapat membahayakan pihak yang tidak bersalah, seharusnya tindakan tersebut tidak boleh dilakukan.

7. Memutuskan suatu tindakan dengan hanya melihat baik buruknya hasil $\quad \begin{array}{llllllll}1 & 2 & 3 & 4 & 5\end{array}$ adalah tindakan yang amoral.

8. Di setiap masyarakat apapun, martabat dan kesejahteraan masing-masing $\quad \begin{array}{lllllll}1 & 2 & 3 & 4 & 5\end{array}$ anggotanya harus mendapat perhatian terpenting.

9. Mengorbankan kesejahteraan orang lain merupakan sesuatu yang sama $\quad \begin{array}{lllllll}1 & 2 & 3 & 4 & 5\end{array}$ sekali tidak diperlukan.

10. Tindakan bermoral dikategorikan sebagai tindakan yang paling $\quad \begin{array}{llllll}1 & 2 & 3 & 4 & 5\end{array}$ “sempurna”.

11. Etika berperilaku tidak dapat menjadi bagian dari kode etik.

12. Apa yang dianggap benar, berbeda-beda dari satu situasi ke situasi lain dan dari masyarakat satu ke masyarakat lain. 
Sangat Tidak Setuju

1
Tidak Setuju

2
Ragu-ragu

3

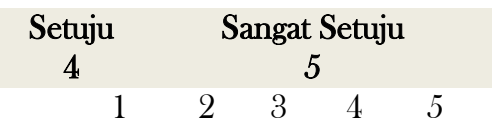

13. Benar atau tidaknya suatu tindakan seharusnya dilihat secara individual, artinya apa yang dianggap benar oleh seseorang mungkin dinilai tidak benar oleh orang lain.

14. Perilaku seseorang tidak bisa dinilai dari benar salahnya tindakan.

15. Pertanyaan tentang tindakan mana yang dianggap benar dan berlaku bagi semua orang, tidak akan pernah bisa terjawab, karena benar atau tidaknya suatu tindakan diserahkan kembali kepada masing-masing orang yang bersangkutan.

16. Penilaian benar atau tidaknya suatu tindakan hanya merupakan pedoman $\quad \begin{array}{lllllll}1 & 2 & 3 & 4 & 5\end{array}$ pribadi bagi seseorang untuk berperilaku, dan tidak digunakan untuk menilai orang lain.

17. Mempertimbangkan etika dalam hubungan antar individu sangat rumit, sehingga orang seharusnya boleh merumuskan sendiri pedoman yang mereka gunakan untuk berperilaku.

18. Merumuskan aturan yang tegas tentang tindakan yang boleh dan tidak boleh $\quad \begin{array}{lllllll}1 & 2 & 3 & 4 & 5\end{array}$ untuk dilakukan, dapat menghambat upaya orang dalam memperbaiki hubungan dan penyesuaian diri di antara mereka.

19. Tidak ada aturan tentang berbohong yang dapat dirumuskan secara pasti, boleh atau tidaknya seseorang untuk berbohong sepenuhnya tergantung pada situasi.

20. Untuk menilai apakah berbohong merupakan tindakan yang bisa dibenarkan atau tidak, bergantung pada kondisi yang melatarbelakanginya.

$\begin{array}{lllll}1 & 2 & 3 & 4 & 5 \\ 1 & 2 & 3 & 4 & 5\end{array}$

$\begin{array}{llllll}1 & 2 & 3 & 4 & 5 \\ 1 & 2 & 3 & 4 & 5\end{array}$

$\begin{array}{lllll}1 & 2 & 3 & 4 & 5 \\ 1 & 2 & 3 & 4 & 5 \\ 1 & 2 & 3 & 4 & 5\end{array}$

\section{$\underline{\text { Skenario } 1}$}

Masha, seorang controller perusahaan, diminta oleh Direktur Keuangan (Sudirman) dalam rapat komite eksekutif bahwa Direktur Utama mereka ingin perusahaan menaikkan modal kerja, dan hal itu sudah final. Sayangnya, Masha bingung bagaimana caranya dapat menaikkan modal kerja, bahkan melalui peningkatan pinjaman, karena pendapatan jauh di bawah laporan forecast yang dikirim ke bank.

Sudirman meminta Masha meninjau kerugian piutang untuk memungkinkan pengurangan dan menahan penjualan lebih lama hingga akhir bulan. Sudirman juga "memutihkan" surat yang diminta oleh auditor dari luar yang menggambarkan "nilai sebenarnya” persediaan spare part.

Pada akhir pekan dirumahnya, Masha mendiskusikan hal ini dengan suaminya Gilang, seorang manajer senior perusahaan lain. Masha mengatakan, "Mereka meminta saya untuk memanipulasi pembukuan”. "Saya merasa dilematis, karena suara hati saya adalah untuk kepentingan perusahaan, namun disisi lain, saya diharuskan benar-benar loyal”. Gilang mengatakan bahwa setiap perusahaan melakukan hal yang sama setiap waktu, jadi hal itu bukan masalah. Gilang meminta Masha untuk tidak melakukan hal-hal yang dapat membuatnya kehilangan pekerjaan karena betapa pentingnya gaji Gilang untuk menjaga gaya hidup mereka selama ini.

Action: Masha memutuskan untuk mengikuti saran pimpinannya.

Evaluasilah tindakan Masha tersebut dengan memberikan tanda silang (X) atas sejauh mana tingkat kesetujuan atau ketidaksetujuan Anda terhadap masing-masing pernyataan berikut ini.

\section{Sangat Tidak Setuju} 1

\section{Tidak Setuju} 2

\section{Ragu-ragu 3}

1. Situasi di atas melibatkan problema etika.

2. Si Aktor (Masha) seharusnya tidak melakukan tindakan tersebut.

3. Saya akan melakukan hal yang sama seperti aktor dalam skenario di atas.

4. Seluruh kerugian (jika ada) dalam skenario di atas yang disebabkan $\begin{array}{llllll}1 & 2 & 3 & 4 & 5\end{array}$ tindakan si Aktor adalah sangat kecil. 


\section{Sangat Tidak Setuju 1 \\ Tidak Setuju \\ 2 \\ $\underset{3}{\text { Ragu-ragu }}$}

5. Kebanyakan orang sepakat bahwa tindakan si Aktor dalam

Setuju 4 skenario di atas adalah salah.

6. Kemungkinan tindakan aktor dalam skenario tersebut bahwa akan $\begin{array}{lllllll}1 & 2 & 3 & 4 & 5\end{array}$ menyebabkan kerugian secara aktual adalah sangat kecil.

7. Tindakan si Aktor dalam skenario di atas tidak akan menyebabkan $\begin{array}{lllllll}1 & 2 & 3 & 4 & 5\end{array}$ kerugian dengan segera di masa yang akan datang.

8. Tindakan Aktor dalam skenario tersebut akan merugikan sangat $\quad \begin{array}{llllll}1 & 2 & 3 & 4 & 5\end{array}$ sedikit orang (jika ada).

9. Keputusan si Aktor akan mempengaruhi rekan kerjanya.

$\begin{array}{lllll}1 & 2 & 3 & 4 & 5\end{array}$

\section{$\underline{\text { Skenario } 2}$}

Miki adalah seorang asisten pengendali Sinar Mas Electronics, sebuah pabrik perlengkapan alat-alat listrik. Miki berusia akhir 50-an dan akan segera pensiun. Anak perempuan Miki baru saja diterima di sebuah sekolah medis, sehingga persoalan finansial menjadi beban pikiran Miki. Bos Miki, yang sedang dalam masa penyembuhan dari sakitnya, tidak dapat masuk kantor, sehingga Miki menjadi penentu keputusan dalam departemennya.

Miki menerima panggilan telepon dari seorang teman lama yang mengajukan permintaan perlengkapan dalam jumlah yang cukup besar secara kredit pada Miki. Miki ingin membantu, namun menyadari risiko jika manambah jumlah penjualan kredit pada perusahaan baru, akan menyalahi peraturan mengenai kebijakan kredit di Sinar Mas Electronics.

Pada saat Miki mangatakan hal ini pada Wawan, seorang manajer umum, Wawan langsung tertarik. Wawan mengatakan bahwa perusahaan punya target penjualan sebesar Rp.2,5 miliar untuk memenuhi budget triwulanan, dan akan menjamin bonus bagi manajemen, termasuk buat Miki.

Action: Miki memutuskan melakukan penjualan pada teman bisnis barunya.

Evaluasilah tindakan Miki tersebut dengan memberikan tanda silang (X) atas sejauh mana tingkat kesetujuan atau ketidaksetujuan Anda terhadap masing-masing pernyataan berikut ini.

\section{Sangat Tidak Setuju}

1

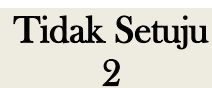

2

$\underset{3}{\text { Ragu-ragu }}$

3

\section{Setuju \\ 4}

1

1. Situasi di atas melibatkan problema etika.

2. Si Aktor (Miki) seharusnya tidak melakukan tindakan tersebut.

3. Saya akan melakukan hal yang sama seperti aktor dalam skenario di atas.

4. Seluruh kerugian (jika ada) dalam skenario di atas yang disebabkan $\begin{array}{lllllll}1 & 2 & 3 & 4 & 5\end{array}$ tindakan si Aktor adalah sangat kecil.

5. Kebanyakan orang sepakat bahwa tindakan si Aktor dalam $\quad \begin{array}{lllllll}1 & 2 & 3 & 4 & 5\end{array}$ skenario di atas adalah salah.

6. Kemungkinan tindakan aktor dalam skenario tersebut bahwa akan $\begin{array}{lllllll}1 & 2 & 3 & 4 & 5\end{array}$ menyebabkan kerugian secara aktual adalah sangat kecil.

7. Tindakan si Aktor dalam skenario di atas tidak akan menyebabkan $\begin{array}{lllllll}1 & 2 & 3 & 4 & 5\end{array}$ kerugian dengan segera di masa yang akan datang.

8. Tindakan Aktor dalam skenario tersebut akan merugikan sangat $\quad \begin{array}{lllllll}1 & 2 & 3 & 4 & 5\end{array}$ sedikit orang (jika ada).

9. Keputusan si Aktor akan mempengaruhi rekan kerjanya

$\begin{array}{lllll}1 & 2 & 3 & 4 & 5\end{array}$

